\title{
TOWARDS A GLOBAL SPACE OF DEMOCRATIC RIGHTS: ON BENJAMIN, GRAMSCI, AND POLANYI ${ }^{1}$
}

\author{
Renate Holub \\ University of California. Berkeley
}

\begin{abstract}
In this article, I approach Benjamin, Gramsci, and Polanyi as members of a particular generation in Europe. Since all three of them were born late in the $19^{\text {th }}$ century, they could not but experience a range of world-historical events. These ranged from World War One, the Bolshevik revolution in Russia, and failed attempts at socialist revolutions on the European continent to the rise of fascism in Italy and Germany, the expansion of European colonialism in the Middle East, the spectacular collapse of the transatlantic capitalist financial system in October of 1929, and the gradual assumption of shared geopolitical hegemony on the part of the United States and the Soviet Union. By the same token, Benjamin, Gramsci, and Polanyi, as European intellectuals, could not but develop their predominant conceptions of the world in the context of a particular space of intellectual systems [Idealism, Marxism, Utilitarianism, Positivism, Historicism, etc]. While all of these intellectual systems involved epistemological, ontological, and ethical standards, some of them participated in the separation of these three provinces of standards from each other, thereby promoting traditions of philosophic - methodological individualization or specialization of branches of knowledge while others tended to continue to methodologically combine these three provinces to various degrees. Benjamin, Gramsci, and Polanyi thus moved in an intellectual space in which there had emerged multiple contests about the relations between ideas and social practices, on one hand, individuals and collectives, on the other hand. All three theorists refused to consent to the political and intellectual appropriation and manipulation of knowledge at the expense of disempowered social strata. As they inquired into the production of spaces in which the conditions for dignified relations between human beings were no longer annulled by
\end{abstract}

1. Anca M. Pusca, (ed.), Walter Benjamin and the aesthetics of change, Palgrave Macmillan, 2010, pp. 10-55. 
political violence, media manipulation, and cultural commodification, they developed the concept of democratic self-organization - in the area of aesthetics, culture, and society, respectively - in order to promote their ideas of democratic communities. In doing so, they had the capacity to think beyond the predominant temporal-spatial imaginations of the transatlantic worlds. No doubt, this accounts for the great interest in these three intellectuals on the part of critical social theorists from all global regions at the beginning of the $21^{\text {st }}$ century.

Keywords: democracy, human rights, Benjamin, Gramnsci, Polanyi

\section{RESUMEN}

Este artículo estudia a Benjamin, Gramsci y Polanyi como miembros de una generación caracterizada por experimentar unos mismos hechos históricos y compartir un contexto en el que predominaban ciertos sistemas intelectuales (idealismo, marxismo, utilitarismo, positivismo, historicismo, etc.). Ello les dio diversas posibilidades de relacionar ideas y prácticas sociales. Los tres rechazaron la manipulación del conocimiento, a fin de defender a los más desfavorecidos. Por ello desarrollaron respectivamente el concepto de autoorganización democrática dentro de los ámbitos de la estética, la cultura y la sociología.

Palabras clave: democracia, derechos humanos, Benjamin, Gramsci, Polanyi.

A arrogancia do Ocidente impede que os chefes de Estado, face a atual crise, se abram a sabedoria dos povos e busquem uma solucao a partir de valores compatihados e duma visao integradora dos problemas da Casa Comum, ferida ecologicamente.

LEONARDO BOFF Brazilian Liberation Theologist March 2009

\section{Introduction: Towards a Global Civil Society}

Walter Benjamin [1892-1940], Antonio Gramsci [1891-1937], and Karl Polanyi [1886-1964] are members of a particular intellectual generation in Europe. Although they spent their childhood and youths in vastly different national socio-cultural milieus and geographic environment - Berlin, Ghilarza-Sardinia, and Budapest/Vienna, respectively - they could not but experience, however directly or indirectly, a range of world-historical events. During their formative years, these included a new geopolitical division of the world as marked by the Spanish-US American War, the Buren War in Southern Africa, and the Japanese-Russian War. In their adult life, these world-historical events ranged from World War One, the Bolshevik revolution in Russia, the 
end of the Ottoman, German, Habsburgian, Russian, and Chinese Empires and failed attempts at socialist revolutions on the European continent, notably in Germany, Italy, and Hungary. These events also ranged from the rise of state fascism in Italy and Germany, the expansion of European colonialism in the Middle East as arranged by the Treaty of Versailles, the spectacular collapse of the transatlantic capitalist financial system on October 24 of 1929, and the nascent assumption of a bipolar geopolitical hegemony on the part of the United States and the Soviet Union. These events intersected in the transatlantic regions with the transformation of the predominant organization of economic production, finance, and markets under the technological conditions of high capitalism [Fordism, Taylorism, Sloanism] and, in a variety of countries in Europe, with the reorganization of state apparatuses and judicial systems after World War One. But they also intersected with the expansion and differentiation of new social formations, especially among the lower middle class strata, a social differentiation which would profoundly impact a reorganization of cultural practices by way of cultural integration of technological innovations such as radio, gramophone, photography, film, automobility, and so on. The political administration of mass societies could now harness the power of culture industries in the organization of the control of mass cultures

As a result of these profound transformations of the political, social, economic, and cultural spheres, intellectuals, qua knowledge organizers, saw themselves confronted with apparently unprecedented philosophical and moral challenges as they scrambled to grasp the relations between social transformations and received ideas. It is no coincidence that relatively new knowledge fields, such as sociology, anthropology, and psychoanalysis, gained entry into academic cultures at this particular historical juncture. Whereas the first aimed at establishing the differences between modern and non-modern social structures, all three of them concentrated their efforts on understanding the relations between individuals and group structures. If until the end of the $18^{\text {th }}$ century the predominant historical tasks of a majority of European intellectuals pertained to the establishment of a human right to critique authority, be it in the realm of politics, religion, or knowledge, during the $19^{\text {th }}$ century the tasks pertained above all to promote the rights to the establishment of non-feudal, nonabsolutist, and non-clerical political orders: the establishment of a modern nation state, that is, based on a separation of powers, electoral systems, and majority rule. In the case of Germany and Italy, as well as other Eastern European regions, intellectual mobilization also focused on national unification. With the rise of the modern parliamentary nation state, based on a modern constitution and a plurality of political parties, including working class parties, this tendency towards future orientation in relation to rights expansion among a majority of the intellectual strata did decelerate. Although the new Western European modern parliamentary nation state, be it in its monarchical or republican 
form, found its existence in the context of a particular mode of production, namely industrial capitalism, a mode of production which historically has been contingent on the reproduction of social classes with unequal access to the control of the relations and forces of production [control of land, labour, capital], the intellectual generation to which Benjamin, Gramsci, and Polanyi belonged on the whole began to increasingly delink their philosophical-moral projects from a collective future based on the expansion of rights. In the social and cultural hegemony of the bourgeoisie, the dominance of private property, privilege, and patriarchy received a renewed lease on legitimacy. ${ }^{2}$ The process of deceleration in terms of the promotion of philosophies of rights expansion is above all apparent in the contests about methodological groundings which erupted in the late $19^{\text {th }}$ century. That one of the founder's of the modern social sciences, Max Weber, would reproduce this contest in his very own methodology is a sign of the times. ${ }^{3}$ As far as the relation between future orientation and rights is concerned, it is true that pre-World War One and pre-World War Two nationalist movements had their brands of nationalist intellectuals, who hailed the future of their nations. But it was not for purposes of augmenting the greater universalization of the space of democratic rights. Conversely, some of the most renowned European intellectuals of the era preferred the past to the future of their respective societies. Freud, Proust, and Weber are all cases in point. ${ }^{4}$ There is plenty of room for speculation concerning this state of affairs. One thing is certain, though. The adventures of the concept of democratic human rights in European intellectual history reflect a curious trajectory. ${ }^{5}$ By

2. This retreat into bourgeois hegemony is particularly apparent with respect to patriarchalism, as the contraction of the transatlantic First Wave Women's Movement [1860-1910] suggests.

3. For studies of Weber's methodology, see Fritz Ringer [1997] Max Weber's Methodology. The Unification of the Cultural and Social Sciences. Harvard UP: Cambridge, MA, USA and London, UK. For a brief historical overview of the location of the social sciences between natural sciences and the humanities, may I refer to my essay "The future of the Social Sciences'. In Journal of Social Sciences, Chulalongkorn University, Bangkok, Thailand, Vol 32, No 1, January-June 2001, Ed. Chaiyan Chaiyaporn, pp. 1-36.

4. I am referring here to Sigmund Freud's Civilization and its Discontent [1929], to Marcel Proust's A la recherche du temps perdu [1913-1927], and Max Weber's powerful images of the "iron cage" and "disenchantment" as evoked in his Protestant Ethics and the Spirit of Capitalism [1905].

5. I define "human rights" not only along registers established by the Universal Declaration of Human Rights by the United Nations, but also along the registers established in the historical tradition of the philosophies of rights. In that tradition, the principle of the right to rights gradually delimited subjection to violence. As a result, its logic points to the abolition of all forms of violence, such as war, and hence to a negation of the "right to war," which subjects human beings to violence in International Rights Regimes. This tendency in the history of the philosophies of rights logically leads to the abolition of theories of the rights to war, including just war theories. 
1910, it had barely emancipated itself from the shackles of predominant Natural Law theories in the context of which human rights variably derived from and were invariably linked to the foundations of divine law. But as soon as the concept of human rights had liberated its own foundations by placing them on a human principle of the right to rights, it began to endanger its newly grounded liberty for justice, equality and expansion of rights by endowing the system of capitalism, with its inherent constraints on the expansion of substantive democratic equality among social strata, with personified attributes of "liberty and freedom" for infinite growth, expansion, and wealth accumulation. Benjamin, Gramsci, and Polanyi are among those European intellectuals who criticized the presumed benefits of such concepts of infinite growth in relation to the expansion of substantive democratic human rights in a finite global space.

Karl Mannheim, who happens to be a member of the very generation of Benjamin, Gramsci, and Polanyi, as well as an important intellectual figure in Polanyi's biography, suggested, as against Marxist and Weberian assumptions, in his seminal work on the sociology of knowledge, that structures of thinking are not only rooted in social place, but also in social time. Whereas the concept of "social space" was derived from a historist and historicist understanding of the materiality of ideas in a historical context, "social time" is a conceptual innovation in that it attempts to grasp the phenomenon of acceleration and deceleration of time in a socio-historical context in relation to rights expansion and rights contraction. Thus social movements, revolts, and revolutions can accelerate the establishment of new democratizing rights institutions, but they can also revert processes of democratization. ${ }^{6}$ Conservative revolutions do exist. Mannheim's investigative gaze was fixed on the early part of the $19^{\text {th }}$ century, when social time accelerated due to the collective impulses towards democratization mobilized by young generations. In other words, the fantasies and imaginations in relation to human rights, identity, and dignity, collectively constructed in word, speech, and image, by young generations, powerfully impacted entire national collectives for a specific period of time. An acceleration in the expansion of a collective consciousness about formal democratic equality, justice, liberty had taken place. If the youth movements in the first few decades of $19^{\text {th }}$ century Europe constitute formidable examples of such social dynamics as studied by Mannheim, the student movements and to some extent the women's movements in the third quarter of the $20^{\text {th }}$ century, which occured in many global regions, do not less so. ${ }^{7}$ The intellectual-moral and spiritual

6. Charles Tilly [2004] Contention and Democracy in Europe, 1650-2000. Cambridge University Press: Cambridge, UK. Sidney Tarrow [2006] The New Transnational Activism. Cambridge University Press: Cambridge, UK.

7. Kurt H. Wolff [1993 ] Ed From Karl Mannheim. 2nd expanded edn. With an Introduction by Volker Meja and David Kettler. Transaction Publishers: New Brunswick (U.S.A.) and 
energies unleashed by the 1960ies have retained some of their force even almost half a century later, albeit that the dispersion of these energies has been uneven. In the 1960'ies, there too obtained an acceleration in the expansion of consciousness in relation to the contradictions in societies subject to the interests of underregulated accumulation of wealth on the part of a minority, the dominance of private property and privilege, that is, in relation to national and global majorities. The facts of continual exploitation of social strata on a national and global level and the facts of multiple processes of commodification of bodies, minds, and souls in the structures of patriarchy, in the midst of administered societies, and in the systems of manipulation of public opinion clashed with a generational critique of the cultural accommodation to these facts on the part of an elite controlled mass media as well as on the part of conformist scholarship. This fractured the cultural hegemony of the bourgeoisie in many layers of civil society.

"1910," or the symbolic date of the onset of theoretical productions on the part of Benjamin, Gramsci, and Polanyi, surely, does not lend itself as readily as the 1830 'ies or the 1960 'ies as an originary historical moment in which the moral-intellectual and cultural directives of young generations accelerated the democratic pace - in formal and substantive terms - of transatlantic history. But "1910" constitutes a historical moment of "social time" in the Mannheimian sense nonetheless, not because it witnessed a relatively homogenous movement, but rather because it witnessed a proliferation of contesting and competing youth movements, political movements, cultural movements, theoretical movements and so on. This proliferation cannot be de-linked, of course, from general demographic increases in the context of capitalist societies from which new social formations, particularly among lower middle class strata, had emerged. This lent itself to the creation of new political, vocational, and cultural organizations and affiliation. By the same token, Europe's capitalist societies, in spite of cyclical crises of the capitalist mode of production which it attempted to counterbalance with forays into all manner of colonialist ventures,

London (U.K.). Original edn 1971. Pp. 351-98. Although in his essays "On the Problem of Generations" Mannheim was exclusively describing the youth movements in Germany, as they constituted themselves among the romantics, Vormaerz and Junges Deutschland, his sociological examination on the concept of "generations" evolved against the background of the work on generations by Ortega y Gasset in Spain and Agaton in France. In the context of the historiography of Spanish cultural traditions, the concept of the "generation of 1898," with central figures such as Machado and Unamuno has become a household term. Italy's $19^{\text {th }}$ century also offers considerable empirical data in relation to significant youth movements, exemplified by Guiseppe Mazzini's organization of "Giovane Italia," on one hand, and by his "Giovane Europa," on the other hand. Interestingly, the question of a United Europe also substantively resonated in some quarters of these organizations which were all involved, to various degrees, in the liberation of Italy from colonial powers and in Italy's political unification: the Risorgimento, that is. 
by 1910 had become relatively affluent. This increase in affluence, measurable on the basis of salary increases of the populations at large in the period from 1870 to 1910 and by the population's increased access to large social infrastructures and social welfare provisions, had also generated greater demands for the organization of leisure [sports clubs, bicycle associations, church choirs, cabarets, cinema, gardening opportunities, and so on]. Moreover, the increase in differentiations of social formations, linked to the technological needs of an expanding economic apparatus, and the political needs of an expanding capitalist state apparatus, is also reflected in the state directed facilitation of greater access to social mobility. As members of the lower middle classes consequently arrived at the university in larger numbers, they too formed their associations and organizations, which obviously were associations of young generations. ${ }^{8}$ The considerable extent of all manner of new organizations, parties, and affiliations, and the public discourses emerging from them, contributed to an expansion of the "public spheres" and hence to a broad social engagement with competing systems of values and conceptions of the world. ${ }^{9}$ If the movements of the 1820'ies, 1830'ies and the 1960'ies were democratically driven, and if, in addition, the movement of the 1960'ies embraced an ethics of pacifism, the ideological contestations defining the social dynamics of "1910" on one hand anticipate the public legitimations of fascisms and national-socialisms of the 1920'ies and 1930'ies, and, on the other hand, they reflect continuity in support of the doctrines of nationalist economic imperialisms. ${ }^{10}$ Mannheim's concepts of "social space" and "social time" are analytically still propitious for apprehending some of the complex conditions under which Benjamin, Gramsci, and Polanyi constructed their intellectual life projects on the concept of democratic self-organization of the expansion of human rights. But since by the early $20^{\text {th }}$ century, transatlantic intellectuals had to negotiate their projects

8. Fritz K. Ringer [1969] The Decline of the German Mandarins. The German Academic Community, 1890-1933. Harvard University Press: Cambridge, MA, USA. He notes that whereas the German universities had an enrollment of 14000 students in 1870, it counted 51000 [excluding 11000 technical students] in 1910 and 72000 in 1918. Not surprisingly, in the 1920'ies, the formation of an academic proletariat had begun.

9. "Public sphere" is a term derived from Habermas's theory of communicative action.

10. Although, as compared to 1910, the doctrines of nationalist economic imperialism have been tempered in recent years, in practice they continue, as trade imperialism, to this day, due to utilization of new international institutional instruments, such as the WTO. As I write these words, in the midst of the global financial crisis, the powerful global economic actors in charge of the WTO would like to resume the DOHA rounds, without consideration of a restructuration of this organization, even though it has tended to privilege the interests of the most affluent economies at the expense of developing economies and developmental states. The recent formation of the $\mathrm{G} 21$ organization is a response to this unevenness in the distribution of control in global trade regimes. 
in the context of modern capitalist mass societies in which new theoretical and new sociological conditions impacted the traditional functions of intellectual work, some modifications of the Mannheimian concepts are in order.

Benjamin's, Gramsci's, and Polanyi's constructed their projects on the principle of the self-organization of democratic rights in relation to the contradictions embodied by the capitalist state. They did so in the context of a complex space which had become subject to at least five major dialectically intersecting intellectual and sociological tendencies. These pertain to 1) overproduction of ideas and theories; 2) expansion of the field of "public thinking and public production of ideas"; 3 ) processes of social differentiation and 4) systematic organization of "intellectual functions" in the disciplines of academic institutions in the service of the maintenance of domination of societies by capitalist economic and state elites; 5) increase in the academic production of "experts" and "specialists" who profess methodological and analytical value-neutrality and scientific predictability of social facts. When Benjamin, Gramsci, and Polanyi engaged in the study of the contradictions between unequal access to the control of the relations of production and the promises of modern democratic constitutions as symbolized by the enlightenment terms of liberty, equality, and justice, these contradictions had become subject to a range of conceptual distortions, displacements, obfuscations, and exaggerations in the context of a mirage of theories. Indeed, the essential character of their "social time" was constituted by an acceleration in the expansion of theories, ideas, concepts, analytical instruments, and methodologies, an acceleration and expansion of ideas which resulted in an overproduction of theories. While debates raged with regards to the proper foundations of methodologies, a principled debate about the conditions and function of this overproduction of theories did not take place, as actual acceleration and overproduction of theories were not questioned in terms of their relevance in relation to the expansion of democracy. ${ }^{11}$

11. Joseph A. Schumpeter [1883-1950] is a contemporary of sorts of the intellectual generation under consideration here. In his monumental History of Economic Analysis, [1954] With a New Introduction by Mark Pereleman. Oxford University Press: New York, USA, he noticed that an overproduction of ideas had taken place by the 1890 'ies, namely in the area of economic theory. He attributes this phenomenon to published debates among economic theorists which often were based on misunderstandings. Nonetheless, he states that too much energy was wasted in these debates. Pp. 759-824. While a sociology of knowledge of the transatlantic worlds throughout the $20^{\text {th }}$ century is faced with intermittent published polemics among members of a field of knowledge in the sense Schumpeter described it in relation to the 1890'ies, one is also faced with a more peaceful overproduction of theories in the last quarter of the $20^{\text {th }}$ century, particularly in the humanist wings of the academies. From the point of view of a non-transatlantic observer, this production is less about contestations and more about a modicum of a collective academic narcissism in the context of an affluent society in which the facts of publications tend to establish their intrinsic value to the accumulation processes of science. Thomas Kuhn demystified these 
Similar to processes of overproduction of material commodities, in the context of which the production of whatever commodities until recently trumped questions about the function of unbridled commodity production in the accumulation of waste, the destruction of ecosystems, and the depletion of natural resources, the processes of overproduction of ideal commodities likewise trumped questions about the function of the relevance of ideas and concepts in relation to dignified relations in social structures, democratic rights, and authentic peace. The overvaluation of the capitalist production process appeared to have informed an overvaluation of the production of ideas under conditions of high capitalism: their relevance was simply intrinsic to their existence. It seems that never before in Europe's intellectual history were intellectuals required to compress into space and time of their own life-time a command of the proliferation of ideas and "isms" which had accumulated on the market place of ideas by 1910. As members of their intellectual generation, Benjamin, Gramsci, and Polanyi were required to command the contests of the faculties" between all manner of idealisms and Marxisms, historicisms and historisms, evolutionisms, positivisms and nihilisms, utilitarianisms and neo-Kantianisms, biologisms and neo-Hegelianisms, relativisms and pragmatisms, phenomenology and pre-Wittgensteinian Cambridge philosophy, including remnants of Natural Law and Natural Rights Theories, not to mention all manner of differentiations in the sociological and psychological fields. While contests of the faculties had occurred at other moments in Europe's intellectual history, never before, it seems to me, had intellectuals met with having to sort out such a vast variety of ontologies, epistemologies, and ethical systems in a single intellectual life-time. The barrage of "isms," whose philosophical relevance and claims to truth was deemed among its respective followers beyond much doubt, was breathtaking.

By 1910, the expansion of a public intellectual sphere, which had obtained throughout the $19^{\text {th }}$ century by way of the launching of new scholarly journals, scientific congresses, publishing houses, and literary clubs, had significantly contributed to this unprecedented proliferation of theories, and hence in an unprecedented production of moral-intellectual systems. Benjamin intuited as much when he remarked that practically every reader, under conditions of modern mass societies, had become a writer, as many economic and bureaucratic activities required the modern subject to engage in a measure of writing. ${ }^{12} \mathrm{Sim}-$ ilarly, Gramsci's analysis of civil society included the study of every possible piece of writing destined for readers, such as a parish newsletter, or a serial

processes already at the beginning of the second half of the $20^{\text {th }}$ century with his The Structures of Scientific Revolutions [1962]. The University of Chicago Press: Chicago, Ill., USA. See also Paul Feyerabend [1987] Farewell to Reason. Verso: London, UK and New York, USA.

12. Walter Benjamin [1980] ,Das Kunstwerk im Zeitalter seiner technischen Reproduzierbarkeit.” In Illuminationen. Suhrkamp Verlag: Frankfurt/Main. Germany, pp. 136-70. 
novel in a newspaper, precisely because civil society is constituted by multiple layers of "intellectual functions." 13 As the "intellectual public sphere" began to turn into a "public sphere" tout court, all members of the public turned into potential producers and consumers of theories, concepts, categories, and values. But they also turned into potential critics of predominant ideas and theories. This expansion of "public intellectuality" ran counter to processes of "social differentiation" intrinsic to modern class societies. While the state, as already mentioned, promoted social mobility through facilitation of access to a university education for members of lower middle class strata, students of lower middle class background were predominantly channeled into the lower orders in the hierarchy of "state professions": into the ranks of grammar school teachers, and not into the rank of the professorial mandarins, for example, or into the ranks of low and middle level bureaucrats, hence not into leadership positions. In Italy, the "state professions" included the "church professions," as peasant and lower middle class families aspired the priesthood for at least one of their sons, as Gramsci noted. It is, statistically speaking, no coincidence that Gramsci, from a disadvantaged background, never finished his university studies, whereas Benjamin and Polanyi, arriving at the university with considerably much more cultural capital, did. The fact that the latter two did not assume university positions after completing their studies is above all linked to the high unemployment rate among university students, where an academic proletariat of sorts had emerged by the 1920'ies. As a result, all three of them ended up making a good part of their living as journalists.

While in the affluent and literate societies of transatlantic capitalisms the majority of populations had become potential public producers and distributors of ideas, their appearance on the historical stage of political actors generated a modicum of anxieties among the traditional intellectual strata. Not surprisingly, the relations between "public intellectuality," namely intellectual functions on the part of educated and thinking citizens along democratic lines of thought and the received role of intellectuals as moral leaders of political persuasion of any kind is reflected in important publications, such as in Ortega y Gasset's La rebelión de las masas and in Julien Benda's La trahison des clercs. These publications squarely pit "public intellectuality" to "received functions" of elite intellectuals, based on the assumption that only elites could and should "function" as intellectuals. In the United States, "public intellectuality" was deemed to assume status of subordination far less ceremoniously to the rule of

13. The concept of a hierarchized "multiplicity" of intellectual layers is particularly apparent in Gramsci's famous essay on the "Southern Questions." Antonio Gramsci [1995] The Southern Question. Tr and intro Pasquale Verdicchio. Bordighera Incorporated: West Lafayette, IN, USA. Original edn 1926, p. 43. 
a few in the name of the "prize of freedom": to the modern public relations agent of Edward L. Bernays Crystallizing Public Opinion [1923] for one, or, somewhat later, after World War Two, to the "public philosophy" of the elite philosopher, for another, as in Walter Lippmann's The Public Philosophy [1955]. ${ }^{14}$ For Benjamin, Gramsci, and Polanyi, the category of "intellectuals," no longer exhausted itself in a $19^{\text {th }}$ century concept of "elite intellectuals", namely "intellectuals" who function as cultural organizers and distributors of dominant belief systems and rules of moral conduct. They made attempts to bring some order into the myriad of claims made about society by leading public intellectuals and the actual practices in every day social, economic, and cultural life. This theoretical ordering of the relations between ideas and practices had become not only extraordinarily complex, all claims to authenticity, truth, and scientificity of the various "isms" to the contrary, but also extraordinarily contested. It is interesting in this context to remember that the capitalist state would attempt to systematically curb this state of affairs. Its state elites by the first few decades of the twentieth century began to channel the synthetic capacities of intellectuals, their "intellectual functions," that is, into the mono-disciplines of the academies. In the context of a hierarchized division of academic labour, the newly established values of "expertise" and "specialization" required a definitive methodological basis, a predilection for specific analytics, a distinct habitus of professionality, and a mono-disciplinary structure of thought. In the European universities run by the state, the university intellectuals to a large extent became "state intellectuals," whose existential survival, including the much coveted pension provisions, tended to variably interlink with the interests of the state. ${ }^{15}$

The "social time" Benjamin, Gramsci, and Polanyi thus shared is that in compressed space of time, namely their life-time, they had to evaluate, juggle, combine, deconstruct and recombine an unprecedented plurality of competing ideas. Their "social time" was compressed in more than one way, however. For they met the theoretical challenges of acceleration in the overproduction of ideas as described above under conditions of fascist and national-socialist threats to their existence. Indeed, as is well known, while Polanyi barely survived these threats, Benjamin and Gramsci succumbed to them. Gramsci pro-

14. Lippmann and Bernays had concurred on the necessity of elite controlled managements of the production of consent in the context of modern democracies long before Lippmann published his book. Walter Lippmann [1955] The Public Philosophy. Mentor Books: New York, NY, USA and Edward L Bernays [1923] Crystallizing Public Opinion. New York, NY, USA. See also Edward L Bernays [1928] Propaganda. Intro Mark Crispin Miller. Ig Publishing: Brooklyn, New York, N.Y., USA.

15. As late as the 1960'ies, Jean Paul Sartre reminded audiences in Kyoto and Tokyo, Japan, that the relations between state and "state intellectuals" in the economic circuits of the transatlantic worlds, which include Japan, had by no means lost their ideological significance. See his plaidoyer pour les intellectuals [1972] Gallimard: Paris, France. 
vides a glimpse of these compressed conditions when he decided to shorten his research program, which he had begun to develop in 1929, in $1931 .{ }^{16} \mathrm{He}$ knew that in Mussolini's prisons, he could not much count on his time. Similarly, Benjamin offers a glimpse of his compressed conditions in a letter written shortly before he approached the Spanish border in August of $1940 .{ }^{17}$ But if their "social time" was compressed, their "social space" was much less so. True, all three of them developed their intellectual projects in a specific national space, and all three projects surely carry the markers of their national cultural unconscious: Benjamin's linkages to the German enlightenment which grounds his notion of aesthetics, Gramsci's obsession with the history of Italian intellectuals, which generates his rich concept of "civil society," and Polanyi's focus on economic theory in relation to anthropology, which runs up against the economic dimensions of the epistemological conceptions of the Vienna Circle as well as the individualist penchants of the ontological foundations of Freudian psychoanalysis. Benjamin, Gramsci, and Polanyi “social space," albeit compromised by despotic threats, largely escaped compression because they developed their intellectual projects not at the centers of the academic establishments, but at their peripheries. They had no membership in the "mandarine club." 18 As a result, their imaginations remained relatively unencumbered by the system of punishment and reward central to main stream academic operations. Their thinking and writing is largely free from the disciplining commands of single academic disciplines, their habitus as intellectuals remains in a constant state of probing, experimenting, questioning. Rather than imposing conclusive, definitive, or synthetic images of the present, their "structures of thinking" remain open to the future eventualities of new social facts or relations. ${ }^{19}$ Even a cursory comparison of their style of thinking as compared to that of Hannah Arendt, for instance, would reveal enormous differences in terms of habitus, language, and perception of intellectual self. ${ }^{20}$ Arendt identified with the field of German

16. For a discussion of this issue, may I refer to Renate Holub [1992] Antonio Gramsci. Beyond Marxism and Postmodernism. Routledge: London, UK. "To realism farewell: Gramsci, Lukacs, and Marxist Aesthetics", pp. 33-67.

17. See his letter to Adorno, dated August 2, 1940, from Lourdes. Gershom Scholem and Theodor W. Adorno [1994] Ed and Annotations The Correspondence of Walter Benjamin. 19101940. Tr by Manfred R. Jacobson and Evelyn M. Jacobson. The University of Chicago Press: Chicago, ILL. USA, p. 637.

18. Polanyi did hold some academic teaching positions, but his academically most important stint at Columbia University came late in life.

19. On of the first translations of Gramsci's work to appear in English was entitled The Open Marxism of Antonio Gramsci. [1957]. Tr and annotated by Carl Marzani. Cameron Associates: New York, NY, USA.

20. May I refer to an article on Hannah Arendt which I wrote over 10 years ago. While I would be able to write this piece today in a more differentiated way, I would still emphasize 
philosophy, and the authoritarian status the field of philosophy, personified by the mandarine philosophers, commanded at the German university of her formative years as intellectual. Her similarity to Martin Heidegger and Carl Schmitt in this respect cannot be easily dismissed. What I would like to propose is that from their respective peripheral stations in the predominant transatlantic organization of knowledge of the $20^{\text {th }}$ century, Benjamin, Gramsci and Polanyi managed to cultivate intellectual liberties which endowed them with the capacity to produce "productive-directive concepts." These are concepts which, although based on analysis and study of complex yet concrete phenomena linked to their own historical epoch, even after six, seven, or eight decades and more offer moral-intellectual directive power to critical social theory. This is so - and here I take the liberty to loosely borrow from Walter Benjamin and Andre Breton - because these concepts "tremble with reflections of the future." ${ }^{21}$ By way of short-hand, let me circumscribe these key concepts as "aesthetics of mass-intellectuality," "civil cultures of societies," and "societies of reciprocities," respectively. As we will see in the second part of this article, the force of these "productive-directive concepts" resides not simply in their rootedness in a space of democratic rights conceptualized since the enlightenment - the right to human dignity in democratic community - a space they share with many critical intellectuals of their generation. The force of these "productive-directive concepts" resides in their capacity to link the concept of the power of democratic self-organization of human rights to dignity in the social relations of communities to locations both inside and outside the "spaces and times" of their own life-times. These included spaces and times outside Europe. While Gramsci knew that he himself would not see his prison writings published, that he was writing for readers who would live after him, and hence for future readers, Benjamin, in his intuitions of the moral forces of the past, endowed generations of trampled historical spaces of Northern and Southern hemispheres alike, with the dignity of linking their past to his own present and hence to the future. Polanyi expressed it most distinctly: I am writing, he said, for the people of the Third World. To concretely imagine these linkages with spaces and times outside the predominant transatlantic imagination is what

Arendt's intellectual identification with a certain habitus of German intellectuality of the first half of the twentieth century. Although the content of Arendt's work, mostly written after World War Two, reflects the intellectual concerns of her new environments in the United States, the structure of her thinking, and hence the style of her writing, is unmistakingly linked to her intellectual socialization into the field of German philosophy. Renate Holub, "Hannah Arendt Not Among the Germans: Intellectuals, "Intellectual Fields" and "Fields of Knowledge" pp. 31. Fall 1997 (http:// learning.berkeley.edu/holub/articles/Hanagf.pdf).

21. Walter Benjamin [1980] ,Das Kunstwerk im Zeitalter seiner technischen Reproduzierbarkeit." Illuminationen, p. 62, Footnote 26. 
Benjamin, Gramsci, and Polanyi, as European intellectuals, do not share with most critical social theorists of their generation. In this, their imaginations indeed "tremble with reflections of the future," a specificity which no doubt explains the extraordinary interest in these three theorists on the part of democratically minded intellectuals from all global regions as global social justice movements and formations of global civil societies have arisen next to the monumental shifts of the epicenter of economic and cultural power from the Atlantic to a plurality of regions in the world, including Asia Pacific and Latin America. ${ }^{22}$ In collectively participating in the invention of this multi-polar future in a substantive and formal democratic key, some of Benjamin's, Gramsci's, and Polanyi's conceptual images, as explicated in the following sections, are invaluable legacies.

\section{Benjamin's “Aesthetics of Public Intellectuality"}

In one of his early essays, entitled "Das Leben der Studenten," Walter Benjamin examined the functions of the German university of his own epoch and arrived at the following conclusions: 1) The university constitutes a space in which a certain percentage of the young generation are socialized into acceptance of the status quo based on a capitalistic class society; 2) The university legitimizes processes of repression and commodification of the mind, soul, and body by predominantly promoting ideologies of accommodation to bourgeois professional and family life. This occurs at the expense of critical thinking, as well as at the expense of neutralizing erotic drives, which amounts

22. For Benjamín I suggest the following publications: Beatriz Sarlo [2000] Siete ensayos sobre Walter Benjamin. Fondo de Cultura Economica de Argentina, Buenos Aires, Argentina; Mauro Ponzi [1993] Walter Benjamin e il moderno. Bulzoni: Rome, Italy; Martin Kohan [2004] Zona urbana: ensayo de lectura sobre Walter Benjamin. Grupo Editorial Norma: Buenos Aires, Argentina; Leandro Konder [1988] Walter Benjamin: o marxismo da melancolia. Campus: Rio de Janeiro, Brazil; and Michael Lowy [2001] Walter Benjamin; avertissement d'incendie: une lecture des theses sur le concept d'histoire. Presses Universitaires de France: Paris, France. The interest in Gramsci in all global regions has found its way in innumerable publications. For an introduction into the global reception of Gramsci's work see Giuseppe Vacca and Giancarlo Schirru [2007] Studi gramsciani nel mondo 2000-2005. Il Mulino: Bologna, Italy. See also: Dora Kanoussi [2000] Ed Gramsci en America. Universita Autonoma di Puebla-Plaza y Valdes Editores-International Gramsci Society: Puebla, Mexico. Dora Kanoussi [2004] Ed Poder y Hegemonia Hoy. Gramsci en la era global. Universita Autonoma di Puebla-Plaza y Valdes Editores- International Gramsci Society-Fondazione Istituto Gramsci: Puebla, Mexico and Rome, Italy. Juan Carlos Portantiero [1999] Los usos de Gramsci. Grijalbo conceptos: Buenos Aires, Argentina. For Polanyi I suggest the following publications. Kari Polanyi-Levitt [1990] Ed The Life and Work of Karl Polanyi. Black Rose Books: Montreal, Canada. Marguerite Mendell and Daniel Salee [1991] Eds The Legacy of Karl Polanyi. St Martin's Press: New York, N.Y., USA. Benoit Levesque [1989] Ed L'autre economie. Presses de l'Universite du Quebec: Montreal, Canada. 
to a strangling of creativity embedded in these drives. The silent legitimation of the widespread use of prostitution on the part of the almost exclusively male student body facilitates such forces of repression; 3) Most students subject themselves, without critique and resistance, to this state of affairs, as even their oppositional attempts remain within the contours of the politics of liberalism on one hand, and, on the other hand, within the social theories promoted by main stream press. By refraining from inquiring into the most profound collective experiences, such as art, poetry, and religion, students themselves destroy the very essence of young generations, namely their potential for unencumbered creativity and innovation; 4) Intellectual revolutions, which once emerged from the sphere of art and social life, could in the era of high capitalism in principle be transmitted by the energy and vision of the young generations, if such capacities were not already doomed to failure due to the academic and political legitimation of an acceleration in the increase of specialization of disciplines and sub-disciplines. Central to these specialization processes are the separation of questions of morality and ethics from systems of knowledge production; 5) Most students have consented to the instrumentalization of their souls for purposes of maintainting routinized institutions of bourgeois professional and family life without asking questions about the conditions these institutions impose on the creative potentials of human beings in relation to a dignified community. ${ }^{23}$ The reason for this state of affairs is to be found in a particular conception of history, Benjamin reasoned, namely one which ultimately assumes the infinity of time. Thus it is only interested in distinguishing the pace of life and epochs, which move fast or slowly along the path of progress. ${ }^{24}$ Yet the fast track of progress, which finds most apposite a separation of morality from the socio-economic and political institutions, and which consequently circumvents the questions of the function of the university in the totality of social relations, is not conducive to authenticity of existence. It pertains to the realization of the creative capacities of human beings in relation to a "menschenwurdige Gesellschaft," in relation to "dignified collective spaces." 25

23. Walter Benjamin [1980] "Das Leben der Studenten," in Illuminationen. Ausgewählte Schriften, pp. 9-21. Original edn 1915.

24. "Es gibt eine Geschichtsauffassung, die im Vertrauen auf die Unendlichkeit der Zeit nur das Tempo der Menschen und Epochen unterscheidet, die schnell oder langsam auf der Bahn des Fortschrittes dahinrollen. [...] Die jetzige historische Bedeutung der Studenten und der Hochschule, die Form ihres Daseins in der Gegenwart, verlohnt also nur als Gleichnis, als Abbild eines höchsten metaphysischen Standes der Geschichte beschrieben zu werden.” p. 9, Illuminationen. Op. Cit. English translation from Walter Benjamin, Selected Writings, Volume 1, 1913-1926, Eds Marcus Bullock and Michael W. Jennings. Harvard University Press: Cambridge, MA, USA and London, England: 1996. P. 36.

25. The concept of "Menschenwürde" has a long history in the context of European cultures, particularly in Italy and Germany. As "dignity of the human being" it was central to impor- 
The programmatic critique Benjamin offered in this essay on the sociological category of German university students and the ideological function of the university in relation to both the geopolitical expansion of transatlantic capitalism and the impact of capitalist relations of production on the structures of everyday social and cultural life anticipates major arguments of the social and cultural critique of the European and North American student movements of the 1960'ies. ${ }^{26}$ While no doubt there obtain national variations in the formation of the transatlantic student movements, there also obtain central similarities. These range from a critique of the predominant pedagogical and curricular models of the universities, intent on producing - through infantalization of the student body - obedience to the status quo rather than critical questioning, and to a critique of the role of the university in the ordering of human relations in a capitalist economy, society, and state. They also encompassed a study of the social division of labour in a class society as well as studies of the function of the authority structures in the family in relation to citizen's obedience to authority structures of the state. Moreover, there were also debates about the academic tendency towards specialization of disciplines at the expense of interdisciplinary research. In addition, there developed, particularly among women involved in the women's movement, systematic analysis of the variability in the social organization of intellectual and erotic drives along gender lines. Where Benjamin's essay on "Das Leben der Studenten" would clash head on with most women in the student movements of the 1960'ies is his assumption that the

tant schools within the humanist traditions in Italy, which attempted to place human capacities of "nolle, volle, posse" on human foundations, rather than on divine foundations [Pico della Mirandola, Ficino, and Valla are good examples]. For an overview in relation to Italian case, see Agnes Heller [1978] Renaissance Man. Schocken Books: New York, N.Y., USA. Earlier attempts to realize such shifts from divine to human foundations of knowledge are inherent in the work of leading Muslim philosophers, such as in the writings of Ibn Ruschd [Averroes] from Cordova, Spain, whose work enjoyed an important reception history in Northern Mediterranean regions outside Spain, such as in France, and Italy. The concept of "dignity" reemerged particularly in the work of German enlightenment thinkers, such as in Fichte. For discussions of this concept in the German enlightenment, see Leszek Kolakowski [1978] Main Currents of Marxism. Its Origins, Growth, and Dissolutions. Tr P.S. Falla. Oxford University Press: Oxford, UK. Pp. 50-80. The most famous example in the history of this concept in the second half of the $20^{\text {th }}$ century is the volume by Ernst Bloch [1972] Naturrecht und menschliche Würde. Suhrkamp: Frankfurt, Germany.

26. Student movements emerged in many global regions, not only in the nation states of the major actors of the transatlantic economies: Europe, North America, and Japan. But the students movements of the transatlantic worlds differ from those in most other global regions to the extent to which transatlantic students did not have to develop their critical projects under the threat of state violence - which often lead to exile, imprisonment, torture and even death - as many students around the world did. Nonetheless, also in North America and Europe some students to various degrees became victims of state violence. 
"necessity of independence of the creative man, [...] is conditioned on the incorporation of a woman (who is not productive in a male sense) into a community of producers, a community based on love [... and that ...] the demand for such a form has to originate among the students themselves, because it is form of life. ${ }^{27}$ Surely, Benjamin here above all critiques those hypocritical dimensions of bourgeois society in which men and women alike legitimate the function of prostitution in student life for purposes of delaying the more respectable social arrangement of marriage until completion of university studies. But his conception of the necessity of the love of women in the life of intellectual and artistic creators, based on the assumption that they are not productive "in the sense of a man," could no longer be shared by the women contingent of the student movement of the 1960's, precisely because the women's movements, which developed parallel to the student movements in the transatlantic worlds, had centered on women's capacities for independently determining the range of their intellectual, moral, and sexual self-realization. That even practically 50 years after the second wave women's movement psycho-social studies suggest that the desire of male control of women's intellectuality and sexuality continues to be reflected in the continual devaluation of women in everyday social and cultural is simply a reminder that Benjamin's universalist take on the supportive but ultimately subservient role of women in the biography of male creative life, which he expressed almost a hundred years ago, is as generational and personal as it is patriarchal and hence institutional. ${ }^{28}$ We know from historical record that while many women of Benjamin's generation in Europe and North America attempted to construct their independent sexual and intellectual lives, relatively few succeeded under the circumstances at hand. But it is also part of the historical record that Benjamin's own relations with women has not been impervious to the gender question: the influence Asja Lacis exercized on the social direction of his thinking is a case in point. ${ }^{29}$

27. "Die notwendige Unabhängigkeit des Schaffenden und die notwendige Einbeziehung der Frau, welche nicht produktiv im Sinne des Mannes ist, in eine einzige Gemeinschaft Schaffender — durch Liebe - diese Gestaltung muss allerdings from Studenten verlangt werden, weil sie Form seines Lebens ist." p. 18, Das Leben der Studenten," in Illuminationen.

28. For a revealing insight into the relation between the continual devaluations of women on the part of some men in everyday social life and some of the psychological dimensions of male sexuality see the excellent recent interview with Rolf Pohl, a social psychologist, which appeared on March 8, 2009, on the International Women's Day, in the TAZ or Tageszeitung in Berlin, Germany. While many feministically trained women have over the past decades developed the analytical tools to deconstruct the foundations of these devaluations, not many men have come forward with similar analyses since the women's movement. For these reasons I consider Pohl's research significant.

29. Frederik Hetmann, [2004] Reisender mit schwerem Gepaeck. Beltz Verlag: Weinheim, Germany. Theodor W. Adorno [1970] Ueber Walter Benjamin. Suhrkamp: Frankfurt, Germany. 
If Benjamin's critique of the German university employs analytical instruments familiar to the projects of the transatlantic student movements of the 1960'ies, it necessarily touches upon major themes which would emerge in the writings of Horkheimer, Adorno, Marcuse, and other intellectuals usually linked to the tradition of critical theory of the Frankfurt School. This is so precisely because the significance of the Frankfurt School is not separable from its dialectical engagement with the "infinite day dreams" of the young generations of the 1960'ies, of which it was but one of many sources. ${ }^{30}$ While some of the most important features of Benjamin's essay on "Das Leben der Studenten" variably anticipate or link up with conceptual images of the Frankfurt School, and the social movements of the 1960'ies, as is apparent from the previous pages, other conceptual images do not as easily entertain elective affinities with critical theory. Among these are Benjamin's concepts of the "present," or Gegenwart, his concept of "mass intellectuality," as well as his concept of "menschenwurdig", namely the right to a dignified existence understood as the "right to violence-less-ness." In order to support my claim, I would like to again return to Benjamin"s essay on the life of students, which begins with the following lines:

There is a view of history that puts its faith in the infinite extent of time and thus concerns itself only with the speed, or lack of it, with which people and epochs advance along the path of progress. This corresponds to a certain absence of coherence and rigor in the demands it makes on the present.

With these two initial sentences Benjamin constructs a framework within which the critique of the function of the university in a particular economy and state takes place. By circling around notions such as "progress," and "epochs," "accelerations and decelerations," "infinite times" and "present," it evokes a conceptual imagery of temporal and spatial movements. This imaginative architecture, which he developed as early as 1915, would be present in Benjamin's thinking to the last writings of his life. Thus it is at work not only in Das Leben der Studenten, which focuses on a critique of the political function of the university, as we already mentioned, but it is also at work when he engages with a critique of the state's range of deployment of violence, as he does in his essay on Kritik der Gewalt [1921]. In addition, when he is critical of the "state intellectuals," due to their tendencies to turn science into fashion, or to

Hannah Arendt [1971] Walter Benjamin, Bertold Brecht. Zwei Essays. R. Piper: Munich, Germany; Momme Brodersen [2005] Walter Benjamin. Suhrkamp Verlag, Frankfurt/Main, Germany.

30. Ernst Bloch [1972] distinguishes between night-dreaming and daydreaming. Whereas night-dreaming manages experiences of the past, daydreaming includes elements of inventive storytelling and anticipations of the future. In his Das antizipierende Bewusstsein. Suhrkamp Verlag: Frankfurt, Germany. pp. 29-44. 
proceed with journalistic superficiality and dilettantism, as he does in Wissenschaft nach der Mode [1931], he is also moving in this very imaginative architecture. It is also squarely present in his Theologisch-politisches Fragment, and his Geschichts-Philosophische Thesen, written towards the end of his life in the later 1930's. ${ }^{31}$ This framework of "progress" and "epoch," "accelerations and decelerations" "infinite times" and "present" centrally pertains to the problematization of the notion of "progress" as it had emerged since the European enlightenment of the $18^{\text {th }}$ century. It happened to sustain a version of progress as promoted by all manner of future oriented "isms," ranging from economic and political liberalisms to Hegelian and Marxist conceptions of historical progress. But it also solicited a rejection of industrial and technological progress on the part of cultural movements, such as romanticism, as well as on the part of all manner of conservative traditions. Benjamin rejected the liberalist-capitalist notion of progress because of its tendencies towards the marketization of art, the repression of aesthetic impulses, and the negation of artistic creativity and freedom. In this posture Benjamin is paradoxically both an heir to European modern aesthetic theory as well as to German enlightenment aesthetics. ${ }^{32}$ But Benjamin's architecture of temporal and spatial movement also runs up against the predominant Hegelian-Marxist conceptions of progress, in the context of which the civilizations of Europe and North America presumably led global societies on a linear historical trajectory. ${ }^{33}$ Benjamin's skepticism with respect

31. Walter Benjamin [1971] Zur Kritik der Gewalt und andere Aufsaetze. Mit einem Nachwort von Herbert Marcuse. Suhrkamp Verlag, Frankfurt/Main, Germany. pp. 29-66. Walter Benjamin [1974] Der Stratege im Literaturkampf. Suhrkamp Verlag: Frankfurt/Main, Germany. pp. 69-72. Theologisch-politisches Fragment in Illuminationen. Op. cit. pp. 262-63. Ueber den Begriff der Geschichte [Geschichtsphilosophische Thesen] in Illuminationen. pp 251-61.

32. While Kant's Critique of Judgment constitutes a basis for modern aesthetic theory in the context of which the realm of aesthetic functions relatively independently from epistemology and ethics, there are interpretations of Kant in which the human capacity of "posse" or potentiality is linked to "volle" and "nolle", and hence to the possibility to engage in the creation of beautiful human communities which are worthy of the dignity of human beings and human relations. This is particularly the case in Schiller"s influential aesthetic theory, where the aesthetic sphere, or the experience of beauty, anticipates experiences of "beauty," "harmony," and "symmetry" in politics: the absence of violence, arbitrariness, and hierarchies, that is. See Klaus Berghahn [2006] "Schillers Aesthetische Utopie." In Regionaler Kulturraum und intellektuelle Kommunikation vom Humanismus bis ins Zeitalter des Internet. Festschrift fuer Klaus Garber. Ed Axel E. Walter. Rodopi: Amsterdam, Netherlands and New York, USA.

33. A struggle of antagonistic forces - be it in the realm of ideas about rights, or in the realm of rights over control of production — leads to a progressively better future for all. In the context of this vision, as Marx synthesized it in the Communist Manifesto, the French revolution had ushered in the victory of the bourgeois classes over and against feudalism, clericalism, and absolutism, just as the eventual victory of the industrial proletariat over the capitalist elites would usher in the end of the oppression of the working class under conditions of unequal relations of production. 
to the traditional Marxist notion of progress is most explicit in his Thesis No 9 of his "Geschichts-philophische Thesen," sometimes rendered as his "concept of history". We will return to this important Thesis No 9 in a moment.

What is central to my argument here is not so much Benjamin's linkages with the Frankfurt School, and his position in the tradition of neo-marxism which many critics have found perplexing. Rather, what I would like to indicate is that in spite of his extraordinary conceptual and moral affiliations with the critical theory of the Frankfurt School - an affiliation which is squarely apparent from the content of his essay on "Das Leben der Studenten, as introduced above - he moved his theoretical project far beyond some of the essential features of neo-marxism and the Frankfurt School by way of a particular disposition: his continual insistence on the concept of the "present." In German, the notion of "present" translates as Gegenwart. All three major notions of time typical of the language structures of the Indo-European languages, such as past, present, and future, display greater semantic simplicity in English, which derived its terminology from Romance languages, as compared to German. The German terms "Vergangenheit," "Gegenwart," and "Zukunft" offer a host of adjectival and substantive derivatives, particularly when endowed with prefixes and suffixes, and hence with extraordinary semantic possibilities in terms of the concepts of space and time. Such permutations are not as readily available in the basic temporal terms derived from Latin. ${ }^{34}$ As far as the noun "Gegenwart" is concerned, there are a series of derivatives, such as the adjective "gegenwärtig," which in turn displays semantic affinities with "geistesgegenwärtig." The latter signals a disposition in which a person, being most attentive to her environment, successfully reacts to a challenge or a shock with the might of her sensuous and intellective capacities. This is a figure of thought immensely common in Benjamin's oeuvre, as has been pointed out in many essays included in this anthology, particularly in the essays by Claes Belfrage's [Cultivating a Mass Investment Culture] and Anca Pusca's [ Benjamin's Concept of Shock]. What I would like to emphasize here is not to much Benjamin's use of concepts of the "present," but rather, his own "Gegenwärtigkeit" or even "Geistesgegenwärtigkeit" in relation to an unprecedented phenomenon: namely, when he "makes present to himself" the unprecedented presence of the masses in urbanized modernities. In fact, while Benjamin makes use of many dimensions of the concept of the "present" throughout his work, none is more powerful than the relation he established between himself as an art critic, essayist, writer, raconteur and art historian and the urban masses surrounding

34. A magician in the handling of prefixes and suffixes with respect to the terminology of time and place is surely Martin Heidegger, as his Sein und Zeit [1926] or Being and Time amply demonstrates. 
him. ${ }^{35}$ In this resides the character of one of his "productive-directive concepts," namely concepts, as I explicated above, which "tremble with the reflections of the future." Unlike traditional elite perceptions of the masses on the part of predominant intellectual strata, Benjamin neither separates himself from the urban masses, he is not afraid of them, nor does he objectify them. As compared to other intellectual formations of his epoch, such as the George Kreis, or the schools of aestheticism, renaissancism, and psychoanalysis, with which Benjamin after all shares considerable interests, he does not erect a protective wall between himself as an individual and urban mass realities. ${ }^{36}$ The self-regulation of individualization does not take place. Rather, Benjamin persistently seeks interaction with and immersion into urban mass societies by performing for them as essayist, book reviewer, radio literary host, story teller, collector, and journalist. When he reflects on the phenomenon of urban mass societies, then he does so in terms of the capacities of modern mass societies in relation to the production of new forms of perception and creativity. In the age of mass literacy, the rise of urban masses carried within itself the rise of mass intellectuality. Urban masses are central to Benjamin's work to the extent to which he comprehended that urban mass society, and hence the masses, were not going to disappear. Most importantly, mass societies potentially generated from within themselves "mass intellectualities." The implications of this fact of modern mass societies in terms of a potential rethinking of the projects of dignified human relations - relations which are liberated from violence - are extraordinarily wide-ranging. Benjamin could only perceive himself as being part of these processes of social and cultural innovations.

The centrality of the concept of "masses" in Benjamin's project is surely apparent in the enthusiasms with which he examined the correspondences between Baudelaire's poetry and the epoch of high capitalism in Paris. But this enthusiasm is heightened when he examines the concept of "mass intellectuality" in relation to new technologies potentially furthering processes of democ-

35. "Not living in the present" is what Benjamin missed among his peers in his essay on student life. There are many dimensions to the Benjaminian use of "present": the present appears as a traditional historical space, such as in the epoch of $19^{\text {th }}$ century social, economic, and cultural Paris. Baudelaire's poetry generates corresponding images, figures, and atmospheric evocations of this "present." Conversely, "the present" of the historical macro space of baroque Germany Benjamin saw crystallized in the microspace of the Trauerspiel. But the "present" is also a social space in which acceleration and deceleration of time intersect. This is surely the case with Benjamin's concept of the flaneur, who, in the midst of the urban, social, and cultural transformations generated by high capitalism takes his time when immersing himself into and when withdrawing himself from the rapid rhythms of capitalist urbanization.

36. For a synthetic overview of the literary-aesthetic environments and tendencies in which Benjamin found himself see Geschichte der deutschen Literatur. Vom Ausgang des 19. Jahrhunderts bi 1917. [1974] Volk und Wissen Volkseigener Verlag: Berlin, Germany. 
ratization on the part of the urban mass societies. This is particularly obvious in his inimitable essay "Das Kunstwerk im Zeitalter seiner technischen Reproduzierbarkeit." ${ }^{37}$ In it, Benjamin not only recognizes the democratic potential of media such as photography and film, in that they enable the majority of the populations to become artistic producers themselves. But he also points out that these new media open up new forms of perception of everyday life. In fact, film technology through optical possibilities can increase the sensation of "being in the present" and hence increase the epistemological capacities of seeing relations from multiple points of view. For Benjamin, these new technologies could link the potential of mass intellectuality to engage in the struggle for dignified human relations between human beings, namely relations which consist in accommodating, rather than undermining, negating, or even destroying, the dignity of humankind. Just as at the end of the $20^{\text {th }}$ century all manner of critical theorists engaged in debates about the new information-technological capacities of networks and the internet in expanding democratizing relations on a local and global scale, Benjamin reflected on linkages between processes of democratization and deployment of new technologies on the part of mass societies. ${ }^{38}$

By relating himself to "mass intellectuality," or to "public intellectuality," as I called it in the first section of this article, Benjamin intuited the self-organizing capacities of democratically oriented collectives in terms of expanding the human rights to non-violent social relations which accommodate human dignity rather than crippling it, threatening it, or even annihilating it. ${ }^{39}$ Surely, Benjamin's mobilization of entire registers of Marxist terms which he repeatedly evokes - "capitalist relations of production," and "oppression of the working class," or "epistemological superiority of the standpoint of the industrial working class" - coupled with the biographical detail of his close relationship with Bertold Brecht tends to support the idea that his project had its share in the traditions of twentieth century western marxisms, and that, therefore, the concept of mass intellectuality should translate into "the intellectuality of the working class avant guardes." This would place Benjamin into the vicinity of an ideological

\section{Illuminationen, pp. 136-170.}

38. Manuel Castells's work on the information age ranks among the most distinguished discussions on the democratic potential of the information-technological revolution over the past three decades. His scientific webpage contains bibliographies and recent essays (http://annenberg. usc.edu/Faculty/Communication/CastellsM.aspx).

39. Habermas's development of the concept of "public sphere" overlaps to some extent with the Benjaminian concepts of "mass intellectuality," which I rendered also as "public intellectuality." But Habermas's central unit of application of his concept remained the nation state, although under conditions of global transformations he eventually did recognize a necessity of thinking about "public spheres" beyond the nation state. Current research on "global civil societies" tends to incorporate the Habermasian concept, but Gramsci's concept of "civil society" is more flexible and promising in this respect. 
position in the context of which the possibility of democratic mass mobilization exhausted itself in the vision of mass mobilization of the industrial working class. But as the dramatic debate between Benjamin and Adorno indicates, even Adorno, whose penchant for aesthetic solutions in response to the structures of capitalist commodification is well known, was not enthused about Benjamin's take on the evolution and interpretation of historical flows in relation to received Marxist conceptions of the dialectic. ${ }^{40}$ It is possible, of course, that in Benjamin's work there simply obtains what he himself astutely noticed in relation to Kafka: namely that profound tensions can run through the life and work of an artist. ${ }^{41}$ This is at least what much of the secondary literature on Benjamin has come to conclude when faced with Benjamin's position between Marxism, on one hand, and, what is sometimes called his Messianism, on the other hand. Such evaluation precludes his precise location in the Marxist camp.

But Benjamin's astute recognition of the extraordinary implications of the unprecedented presence of urban mass societies opens up a vista which remained closed to more traditional versions of Marxism. True, masses existed before the $19^{\text {th }}$ and $20^{\text {th }}$ centuries. But never before existed the potential that masses, rather than elites, could promote their own versions of the nature of human relations. This implies that masses of people are capable of the selforganization of practices and social relations bent on exiling ideas and practices of violence from everyday life. As Benjamin noted, under national-socialism, mass culture was controlled by the elites. The theatres, the stadiums, the film ateliers, the publishing houses all were managed by the visions of the Nazi regime. But the monumental art produced by fascism had no function for the future, because such art, in its monumental material conditions, was not reproducible by people. Hence it was profoundly undemocratic, as it precluded reproducibility. In Benjamin's reflections on mass societies, with its direct linkages to mass intellectuality in relation to new technologies, there squarely resides a glimpse of the possibility of the organization of mass intellectuality on a global scale: the organization of global civil societies, that is. Hence mass society, in itself was not necessarily destined by historical fiat to become, as historical object, subjected to administration, manipulation, and deception by well-organized elites. While in the work of Marcuse, Horkheimer, Adorno and other critical theorists mass societies were primarily viewed in terms of what they denied to authentic human existence, in the work of Benjamin, mass societies, in their potential of generating "mass intellectuality" or "public intellec-

40. Michael Lowy has repeatedly written beautiful pages on Benjamin's imagination of historical flow. See Michael Lowy [2001] Walter Benjamin; avertissement d'incendie: une lecture des theses sur le concept d'histoire. Presses Universitaires de France: Paris, France.

41. See his review of "Max Brod, Franz Kafka. Eine Biographie." In Der Stratege im Literaturkampf. p. 85. 
tuality" contained the promise of building new social relations between human beings, relations which were not simply relations but which were "menschliche Beziehungen." Again, such a concept is reminiscent of the Marxist philosophical apparatus. But in Benjamin's work, the concept of the possibility of "menschliche Beziehungen" is linked to "Menschenwürde." This enables him to link the present of authenticity, as desired by the critical theory of the Frankfurt School, to a past in which human dignity any where in the world had been annihilated due to its subjection to extraordinary acts of violence..$^{42}$ Collectives in the present can redeem such violence by exiling practices and ideas of violence from their respective societies. "Progress," for Benjamin, then, is not "progress" as understood in the tradition of the European enlightenment. As he writes in his Thesis No 9, the Angelus Novus, as painted by Klee, resembles "the angel of history." The angel is caught in a storm, which, originating in paradise, forces the angel to move towards the future, with its face looking towards the past. All the angel can see with horror in this storm are the mountains of rubble of the past, signs of violence and deaths, which reach the sky. What we call progress, Benjamin writes, is this storm. ${ }^{43}$ Whoever has inhaled the air at haunted places of rubble, where masses of people have been dehumanized by violence, knows that our present is linked to the past, as Benjamin inimitably evoked. What would it mean if masses of people in the world today, "public intellectuality," that is, would redeem the past of violence with an all-encompassing refusal of promoting violence in the structures of everyday social, cultural, intellectual, and geopolitical life? These are "productive-directive concepts" which patiently wind their way through the pages of Walter Benjamin as they unmistakingly "tremble with reflections of the future."

\section{Between Gramsci's "Civil Cultures of Societies", Polanyi's "Social Cultures of Reciprocities" and Benjamin's "Aesthetics of Public Intellectuality" in the Information Age}

If Benjamin brings into his field of moral vision the suffering of conquered peoples in the past anywhere in the world in relation to the responsibil-

42. Ernst Bloch's use of the term "Menschenwürde" is central to his project. But in contradistinction to Benjamin, Bloch emphasizes social or organized manifestations of this desire for human dignity throughout European history. He traces this organized desire in his monumental three volume study The Principle of Hope. In other words, whereas Bloch uses the existence of this desire or principle as evidence of its historical irreducibility, Benjamin's accent is on linking this historical irreducibility, in the remembrance of violence on the part of present generations, to the abolition of violence. Ernst Bloch [1974] Das Prinzip Hoffnung. Suhrkamp: Frankfurt, Germany. Written in exile in the United States 1938-1947.

43. Illuminationen, p. 255. 
ity of "public intellectuality" of the twentieth century, Karl Polanyi and Antonio Gramsci engage their thoughts about future eventualities of new social realities on a global scale with relations between present and past collectives as well. Such intellectual habits hardly assign transcendental status to the concept of individualism and the theories of individualism it sustains in the area of political, geopolitical, social, and economic thought. Hence all three theorists attempted to grasp both the synchronic and diachronic dimensions of the dialectical relationships between individuals and communities, a relationship which is the informing basis of creativity, innovation, and future-orientation, as expressed in languages, religion, art, and other material and ideal institutions. ${ }^{44}$ In other words, all three theorists distanced themselves from the hegemony of the concept of the "individual," on the basis of which predominant social, political, and geopolitical theories assume that competitive rules of conduct naturally determine all manner of actions in relation to dominance and subordination..$^{45}$ These range from individual action vis-a-vis other individuals, or actions of individual social strata vis a vis other other social strata, to the individual actions of nation states vis-à-vis other nation states. On the subject of Gramsci's understanding of the relations between past, present, and future, I would like to point to an extraordinary passage in Gramsci's Prison Notebooks. For already in the early 1930's, Gramsci wondered in his prison cell about future economic transformations of East Asia: "Concerning the function of the Atlantic in civilization and the modern economy. Will this axis move to the Pacific? The largest populations in the world are in the Pacific East. If China and India would become modern nations with large masses of people involved in industrial production, their separation from European dependence would indeed break the actual balance: hence transformation of the American continent, the shift of American life from the Atlantic to the Pacific etc One should look at all of these questions in economic and political terms, trade terms, etc. ${ }^{46}$ While intellectuals living under colonial or semi-colonial conditions in Africa, Latin America, and Asia had begun to critically think

44. Michael Buroway has published a most informative essay on Gramsci and Polanyi. "For a Sociological Marxism: The Complementary Convergence of Antonio Gramsci and Karl Polanyi." Politics and Society, vol. 31, No. 2, June 2003. Pp. 193-261. He too stresses the collective conditions of creativity and innovation, the most essential expressions of which is the capacity for social self-regulation.

45. Social Darwinism is sometimes used to describe this form of individualism, but a deeper understanding of the predominance of the concept of the "individual" in social science theories, in public policies, in public discourse, and in public self-perception would require a comparative study of individual nation state cultures. I tend to hypothesize that significant variations would obtain.

46. Antonio Gramsci [1975] Quaderni del Carcere. Ed Valentino Gerratana. Vol 1. Einaudi: Turin, Italy. p. 242. Written in prison between 1929-1933. 
about the future of the political economies of their region, few critical intellectuals of Gramsci's generation had significantly reflected on the eventuality of such momentous transformations which would move the epicenter of the global economic weight from the Atlantic to the Pacific. ${ }^{47}$ The implications in terms power shifts evoked by Gramsci's inquiry were even less a matter of substantive debate among leading transatlantic intellectuals of Gramsci's epoch, where all manner of colonialist and imperialist ventures, which had been harnessed in the service of gaining advantage in the unrelenting capitalist competition for raw materials, investment opportunities, and market shares assisted in the predominant definition of self-perception and identity of transatlantic national citizenries in relation to the rest of global populations. If $19^{\text {th }}$ century cultures in Europe had generated a variety of nationalisms, in the context of which nations intermittently proclaimed their cultural superiority vis-à-vis other nations in Europe, by the early $20^{\text {th }}$ century the perception of European superiority in relation to other global regions found its most apposite expression in many important publications. Max Weber's introduction to the Protestant Ethic and the Spirit of Capitalism, where he traces the distinctions of Western science, mathematics, historical thinking, art, architecture, music, law, political institutions and so on, is representative of such expression..$^{48}$ For only cultures of Europe and North America, he reasoned, had generated capitalism. While Weber's depiction of the transatlantic scientific and cultural achievements attempted to avoid positive moral evaluations of occidental modernity, the nexus between a presumed superiority of the European mind and morality, and hence of the institutions of European societies and cultures, had been systematically implanted into the cultural unconscious particularly under conditions of high capitalism..$^{49}$ With some exceptions, Europe's and North America's exception-

47. W.E. Burghardt Du Bois [1996] The World and Africa. An inquiry into the part which Africa has played in world history. International Publishers: New York, N.Y., USA. First edn 1946. Aime Cesaire [1972] Discourse on Colonialism. Tr Joan Pinkham. Monthly Review Press: New York, N.Y., 1972. Original French edn 1955. Frantz Fanon [1964] Toward the African Revolution. Tr Haakon Chevalier. Grove Press: New York, N.Y., USA.

48. Weber wrote the "introduction" many years after the publication of the Protestant Ethic, namely in 1920. Current editions tend to use it as a regular introduction, as if he had written it in 1904 or so, thereby linking his statement of European distinctions to his detached presentation of the rise of capitalism in relation to protestant value bearers in Western societies. What the introduction indicates, however, is his concern about criticism of his thesis on the part of non-eurocentric anthropological and ethnographic research. Karl Polanyi's studies, based, as they were, on anthropological and ethnographic research, are indeed powerful statements about the shortcomings of Weber's understanding of the irreveresable trajectory of transatlantic rationalities. See Max Weber [2003] The Protestant Ethic and the Spirit of Capitalism, tr Talcott Parsons. With a Foreword by R.H. Tawney. Dover Publications, INC. Mineola: New York, USA. Author's Introduction pp. 13-31.

49. Edward Said has masterfully traced the present of such unconscious in the predominant European mind, above all in his work on orientalism. Janet Abu Lughod, Andre Gunter 
ality remained its preferred object of study, among liberals, conservatives, and leftists alike. ${ }^{50}$

That Gramsci would reflect on the impact of possible economic transformations on the future of all global regions is not surprising, if we take into account that he was not simply a European intellectual. He was, above all, a "Southern" intellectual, both born into modest social and cultural capital of Italy's South and into a modest hegemonic capital of Southern Europe. As such, he was attuned to issues pertaining to regional variability in relation to resource allocation, or to national variability in terms of access to the control of market shares in global trade and investments. He knew something about the political economy of the production of dependencies on the national and international level. In the national planning of its political economies after reunification in 1871, Italy's elites had assigned a subordinate economic role to the Italian south by the organization of a capital intensive industrial mode of production in the north and a predominantly labour intensive agricultural mode of production in the south. Gramsci would dedicate a systematic study to this factor in variability. It had facilitated a continuous exploitation of illiterate peasant masses by southern landed elites, intensified social discrepancies between the North and the South in terms of access to educational, cultural, and professional opportunities, and it had seriously compromised the participation of the peasant masses in the political process. ${ }^{51}$ All three factors played a substantive role in the support the fascist regime enjoyed in the ranks of the southern rural petty bourgeoisie, whose spontaneous fear of the large peasantry generated their seizure of the role of mediators between the ideology of the southern landed elites, aligned with the capitalist industrialist elites of the north in a historic bloc, and a disaggregated, fragmented, passive and hence ideologically disoriented, mass peasantry in the South. ${ }^{52}$ In other words, the uneven development between the industrial north and the agricultural south had but generated most fragile "civil cultures in Italian society," in the context of which

Frank, and Peter Gran, among others, have studied the contingent relations which obtained between the rise of transatlantic capitalism and other global regions. Systems theorists, among them Immanuel Wallerstein and Giovanni Arrighi, have furthermore indicated the dependencies of transatlantic economies on the circuits of commerce and trade in Asia during the rise of capitalism.

50. The exceptions one can find most easily in the sphere of painting and music, such as in Picasso's turn to African shapes or the evolution of twelve tone music, or in the area of critical ethnography and critical anthropology.

51. Illiteracy was a variable which denied peasants electoral rights up to almost the entire first decade of the twentieth century. Given Italy's high illiteracy levels, still over over $70 \%$ in the 1870 'ies in a population of 20 Million, and the concentration of it in the south, the exclusion of the peasantry from parliamentary politics indeed enabled a minority to decide on the future of the young nation state.

52. Antonio Gramsci [1995] The Southern Question. Original Italian edn 1926. 
the disparate levels of consciousness in relation to rights expansion compromised social cohesion and cultural homogeneity in relation to norms and application of democratic rights. By the same token, in the organization of international economic, trade, and financial regimes of high capitalism in the period of 1870-1910, Italy's location on the southern periphery of Europe had among a variety of factors impacted the pace of its capitalist evolution in terms of production, trade, and investments, and hence the limited status and sphere of influence on the roundtable of predominant international capitalist actors. As a result, although the Italian government of high capitalism pursued colonialist interests in Africa, notably in Ethiopia and Lybia, its participation in the international "Scramble for China" is practically non-existent. ${ }^{53}$

There may have been other reasons why Gramsci paid attention to the East. For one, Italy's strategic position in the Mediterranean, and hence on one of the worlds most important international maritime transportation routes between Europe and Asia, practically since the end of the Renaissance had been of foreign policy interest to the empire builders in Europe, such as England, Austria, Spain, and France. Italian intellectuals were aware of it, Machiavelli's writings representing one of the earliest examples of such awareness. With the construction of the Suez Canal, the strategic position of Italy in the East-West transportation systems had become even much more of an issue - for Europeans and Italians alike - as Italy's proximity to the Suez Canal, a most vulnerable conduit between the Mediterranean, the Red Sea, and the Indian Ocean, increased the significance of access to the spheres of influence in relation to the control of Italy's foreign relations program..$^{54}$ Further, Gramsci may have heightened his interest in the Pacific while sojourning in Moscow in the early 1920's. After all, Russia's historically consistent imperialist outlook towards the East had dramatically accelerated during the $19^{\text {th }}$ century as it engaged, next to Britain, France, Germany and the United States, in economic, diplomatic, and financial processes which contributed to an acceleration in the disintegration of the Chinese empire. Russia reversed this trend by developing new policies, particularly after the Chinese revolution of 1911-1912 and the May $4^{\text {th }}$ Movement which led to the foundation of the Communist Party in China

53. Given the innumerable forays into Asian, particularly Chinese territories on the part of transatlantic capitalist powers - by way of securing concessions for ports in China, by leasing waterways, or by way of investing and controlling profits from railroad construction in China, not to speak of ending historical tributary relations between China and contiguous nations by annexing entire territories as occurred in Burma by the hands of the British, and in Vietnam by the hands of the French - Italy's participation in these ventures is most minimal, for good reason: it did not command the means for it.

54. Luciano Russi [1981] Nascita di una nazione. Ideologie politiche per l'Italia [18151861]. Clua: Pescara, Italy. 
1920. In fact, by the 1920's, the Soviet Union had offered, by way of the $\mathrm{Ka}$ rakhan Manifesto, to return much coveted railroad concessions in China to the Chinese government, while simultaneously sending advisors to assist in the building of a fledgling Chinese communist party. In other words, although Gramsci composed his thoughts on the future of the Pacific region when India was still a colony under British rule and when China, internally divided by innumerable civil strives, was threatened by Japan's invasion of Manchuria, he was too much of a historical, political, economic, technological, and geopolitical thinker not to reflect on the dialectic between the evolution of the organization of processes of industrial-technological production and the organization of regimes of international relations and trade. Indeed, it was only ten years or so after his death in Mussolini's prison that India had gained independence from Britain, thereby launching into existence the largest formal democracy of the world. Conversely, China, as a sovereign republic, had begun to consolidate its communist revolution under the leadership of Chairman Mao Ze Dung by 1949. Both countries had begun to consolidate under sovereign control the organization of their economies and societies along capitalist and socialist lines, respectively. By 2009, the increasing globalization of processes of organization of production, finance and trade, which accelerated, by way of information-technological revolutions of the 1990's, the transformation of industrial capitalism into informational capitalism, has begun to encompass not only India's economies organized along capitalist lines, but also China's economies, the precise nature of which remains a matter of considerable debate in the predominant economic literature.

What renders Gramsci's comments of the early 1930's on India and China so prescient resides in the obvious fact that by 2009 China and India have indeed become substantive players in the organization of the global economy and trade as well as of international relations. ${ }^{55}$ Their new global status is apparent above all through their investment and diplomatic strategies in the context of global developing economies. Moreover, the increase in the size of the workforce in India and China has contributed to their productivity growth, as the low labour costs in both countries tend to attract investors. The proliferation of technological applications in the capitalist production processes which facilitates increases in productivity, has neither made contingent the variable of cheap labor in the equation which measures productivity growth, nor has it impeded the expansion of expensive labour, as salary surpluses are the condition for the purchase of commodities, as Gramsci noted already in his notes on "Americanism and Fordism," in which he analyzed the persistence of the extraction of surplus value from wage labour in the capitalist production process

55. Both nation states are represented on the United Nations Security Council, and both nations are member of the G21. 
notwithstanding the unprecedented application of technological innovations in its organization..$^{56}$ In other words, even seven decades or so after Gramsci's essay on "Americanism," labour intensity still constitutes a key variable in the equation of productivity growth, even under conditions of the modes of production of informational capitalism which tends to be technology intensive and capital intensive. Moreover, Gramsci's reflections in the 1930's on the spatial transformations of the economic organization in the United States is of incisive interest, since in the economic history of the North American continent the most advanced and profitable economic sectors - information-technologies, aviation and space technologies, military technologies, nano-technologies, medical technologies and so on - have indeed moved to a large extent towards the Pacific Coast, to California, Oregon and Washington, that is, particularly since the end of World War II. Silicon Valley may serve as the most illustrious example, as it represents not only one of the most important backbones of global informational capitalism, but also a global center of innovation, creativity, and invention of new forms of global democratic interactions linked to the liberatory potential of the internet. ${ }^{57}$ Both functions are intricately interwoven with the attraction of talent from around the world, including from India and China. Since the advent of the internet, the edge the traffic in volume and speed commanded between North America and Europ as compared to North America and Asia is in process of gradual diminuition. While all these factors mentioned above point to a remarkably anticipatory content of Gramsci's reflections on the status of China and India in $21^{\text {st }}$ century world history, what appears to me to be even more groundbreaking are the questions he raises with respect to the political impacts on the "civilizations of modernity" generated by the shift of the epicenter of the economic weight from the Atlantic to the Pacific. Do his questions not imply that the status of Eurocentric culture and power could be minimized, or even displaced by such enormous shifts? ${ }^{58}$ Does it not follow that new cultures could emerge beyond the "civilizations of modernity," including new "civil cultures of societies?"

56. "Americanism and Fordism" in Antonio Gramsci. Selections from the Prison Notebooks. [1971]. Ed Quintin Hoare and Geoffrey Nowell Smith. International Publishers: New York, N.Y., USA. Pp. 279-322

57. The literature on information technology can be divided into three major currents: 1) the pessimistic literature, which focuses on the uses of information technology for purposes of control and surveillance of modern citizenries; 2) the celebratory literature, which tend to view all manner of electronic gadgets as signs of civilizational progress; 3 ) a democratic tendency, which stresses the liberational potential of information technology by way of judicious application and use of it. Manuel Castells's research over the past 15 years has been particularly important in terms of discussing the democratic potential of information technologies

58. Goran Therborn, [1997] "Europe in the Twenty-first Century. In Peter Gowan and Perry Anderson, eds. The Question of Europe. Verso: London, UK. pp. 357-385. 
It would be difficult to make the claim that the Prison Notebooks offer a fully articulated architecture of new "civil cultures beyond modern societies." After all, Gramsci was mostly interested in an analysis of the political and ideological fields of Italian society under the capitalist and fascist nation state, under which he lived. In such analysis, he developed the central concepts of civil society, political society, intellectuals, and hegemony, the four pillars of his critical theory. These concepts were useful to grasp the operations of both fascist and capitalist hegemony. But Gramsci also constructed elements for cultural strategies designed to participate in the replacement of the domination of Italy's economy, politics, and culture by a minority of elites with the self-organized power of the masses of the working people. There is no doubt that the industrial proletariat and its organizations are central to Gramsci's conception of self-organizing capacities of societies, particularly in light of the fact that he, as all other intellectuals of his generations, developed his visions of future against the background of the rise of the Soviet Union. Yet by the same token, the organized proletariat in Italy was charged by its leadership with creating political alliances with many social and political constituencies in order to resist fascism. Among these alliances are those with the liberal intelligentsia. ${ }^{59}$ True, in his paragraph on Asia Gramsci evokes the notions of "modern state" and "industrial production," such that his vision of future historical possibilities appears to be exclusively linked to the political organization of industrial working classes in Asia: this evokes visions of socialist or communist or social democratic internationals. However, since Gramsci does operate in his very paragraph on Asia with terms such as "economic, political, trade, etc," as we recall from above, his field of analysis about the future relations between the political economies of the Pacific and the Atlantic is dialectically expandable at least in two significant ways. First, by using the term "political" in relation to production and trade, he establishes a dialectic between the politics of the "internal, or domestic politics" and politics of the "external, or international politics." ${ }^{60}$ Since domestic politics find their expression in political society and civil society, the relations between these two political forces are not independent from external politics in the area of trade, finance, and pro-

59. Among the alliances he suggested was one with the important liberal intellectual Piero Gobetti, author of the concept of the "liberal revolution." An interesting introduction to his style of thinking is Piero Gobetti 1995] La filosofia politica di Vittorio Alfieri. Grafiche Cesari: Ascoli Piceno, Italy. Written in 1922.

60. For establishing relations between "politics," "international politics," and "economics," see the interesting essay by Sabine Kebir [1999] "L'internazionalismo di Gramsci e i problemi odierni della sinistra." In Giorgio Baratta and Guido Liguori, eds Gramsci da un secolo all'altro. International Gramsci Society and Editori Riuniti: Rome, Italy. Pp. 211-17. In addition: Andreas Bieler and Adam David Morton [2006] Images of Gramsci. Connections and contentions in political theory and international relations. Routledge: London, UK. Mario Proto [1999] Ed Gramsci e l'Internazionalismo. Nazione, Europa, America Latina. Piero Lacaita Editore: Manduria, Bari, Rome, Italy. 
duction. Secondly, since "international politics" proper find expression in a variety of regimes, agreements, organizations, associations etc on the international as well as the transnational level, associations, these structures of the "international" in their complexity are also in a dialectical relation with "internal politics" of a particular nation state ${ }^{61}$ The implications of the complexity of this nexus in relation to "new civil cultures of societies" on a global scale are not developed to any extent in Gramsci's paragraph on Asia, but given his thoughts on the recognition of this nexus opens up a horizon of new possibilities. In other words, his reflections about future historical possibilies can now be organized along two axes. The first hinges on constructing social and political relations in Italy in the context of which human beings can live and work together with dignity in the context of social collectives of formal and substantive democracies. These are states based on the rule of law, economies which minimize the exploitation, oppression, or the commodification of the majority by a minority, societies which tend towards the exclusion of violence from their institutions and theories, cultures which selforganize themselves through democratic communication, solidarity, friendship, reciprocity, and non-contractuality. The second hinges on his understanding of the dialectic between domestic and international politics, into which international production, finance, and trade regimes are embedded, as is apparent from his paragraph on Asia, in relation to his epistemological approach to the knowability of the future, of which he treats in other sections of the Prison Notebooks.

In order to delineate Gramsci's approach to the future, it is useful to look at one of his discussions of the philosophy of Benedetto Croce in his Prison Notebook No 10. In an "Introduction to the study of philosophy" Gramsci engages with the Kantian concepts of numina and phenomena, whereby the first, as is well known, denominates "the thing in itself which one cannot know" and the second "the phenomenological world which is knowable." 62 While Gramsci calls into question is the "objective status" of the phenomenon in the Kantian system, in that objective knowledge, conceived along Hegelian-Marxist lines, is always interested knowledge linked to a subject's interests and needs, he relocates the noumenon into a space of knowability in that he proposes that "objective knowledge," due to its tendentially exclusionary practices generated by interests and needs, simultaneously produces an "extra" or a "surplus" of "knowable entities" which remain outside the purview of the subject's epistemological enterprise. Such surplus may be eventually accessible to knowledge

61. I would like to refer to my essay "Transcommunality in a Global World" [2003] in John Brown Childs. Transcommunality. From the Politics of Conversion to the Ethics of Respect. Temple University Press: Philadelphia, USA. pp. 146-57. Also see Partha Chatterjee [2006] The Politics of the Governed: Reflections on Popular Politicis in Most of the World.

62. Antonio Gramsci, [1977] Quaderni del Carcere. Ed Valentino Gerratana. Vol. II. pp. 1290-91. 
acquisition on the part of the subject through the refinement of intellectual instruments generated by the transformations of social and technical conditions. As far as the future is concerned, "historical prevision, or historical foresight consists simply in that act of thought which projects into the future a process of development which is based on the study of those processes which led from the past to the present." Against the background of the concept of "surplus knowledge," the accent of the epistemological linkages about past and present thus appear in relation to the rise of new instruments of knowledge generated by new technological conditions.

Indeed, in his analysis on the relations that obtain between past and present in Italy, in his study of the status of "civil cultures of contemporary Italian societies" that is, Gramsci systematically studied, all appearance of unsystematicity to the contrary, the processes of development of democratic public spheres. One of the key analytical concepts pertains to Gramsci's study of uneven development in Italy. This unevenness in development is due to the uneven penetration and distribution of a consciousness of the self-organizing capacities of collectives in relation to restricting institutional and theoretical norms of violence and rules of conduct. Gramsci uses the terms of uneven cultural and moral preparation of the Italian people when discussing the unevenness of a "longue duree" of what Benjamin would have called "public intellectuality." In order to combat this unevenness in "civil" preparation, Gramsci develops his theories of critical pedagogy, in which pedagogies of the oppressed, and adult education play an important role, as does the idea of the implementation of discipline in education on all scholastic levels. ${ }^{63}$ Gramsci, who compares Italian "civil cultures" to those of Germany, France, and Britain, registers a wide deficit in democratic consciousness in Italy due to the immense heterogeneity in moral and intellectual preparation. The "public intellectuality" Benjamin intuited in the German context, due to the relative homogeneity of German civil cultures which had evolved since the reformation, was absent from the civil cultures in Italy. ${ }^{64}$ By inquiring into the democratic deficits of Italy's civil cultures, Gramsci developed a comparative sociology of intellectuals in Europe. In this comparative study, he noted that French enlightenment philosophers had systematically participated in the state-wide preparation of the French revolution. The political impact of the French revolution on French "public intellectuality" at large

63. There is a large literature on Gramsci's theories of pedagogy, educational philosophy. For an introduction, see Carmel Borg and Peter Mayo [2007] Public Intellectuals, Radical Democracy and Social Movements. Peter Lang: New York, N.Y., USA.

64. The important paragraphs of his comparative study of European national intellectualities are in the Quaderni No 1, paragraph 154, Quaderni No 2, paragraph 49, and Quaderni No 3, paragraph 31, 48, 51, 142, Quaderni No 4, paragraph 3. The concept of "translatability" provides a cohesive thread for these various paragraphs. 
was translatable into the central significance of German idealist philosophers in the education of the German public on the principle of the right to rights. In other words, although no political revolution had taken place in Germany, German idealist philosophy functioned as a political movement. Conversely, English political economy, such as had been developed by Adam Smith and David Ricardo, also translated into a political force towards the expansion of a collective consciousness on the principle of the right to democratic rights. In Italy, Gramsci found due to the proliferation of cosmopolitan intellectuals who had preferred to link their fantasies to membership in an ideal republic of European literati, intellectuals overall had made little use of their capacity to translate the English, French and German experiences into an Italian context. The historical formation of significant "public spheres" had not taken place. Italy's "civil cultures of societies still awaited their futures. Although Gramsci, in light of the passive revolution in Italy which had been ushered in since its unification in the 1860 'ies remained in general skeptical about possible accelerations in the formation of democratic public spheres in Italy, his own cutting edge thinking in relation to Asia Pacific, where politics intersects with trade, production, and finance in geopolitics, coupled with his epistemological insights, actually do undermine his skepticism. For did he not ponder the possibility of an acceleration in democratic knowledge acquisition due to technical advances? Did he not propose that transformations of social and technical conditions could generate and refine new intellectual instruments useful for acquiring knowledge of those aspects of reality which hitherto escaped the self-interested gaze of the subject? Indeed, with the advent of the internet, into the technology of which is embedded extraordinary potential for innovation in democratic or public communication between self-regulating democratically oriented communities, Gramsci's horizon of the linkages between multiple structures of the "international" and the "national" can enlighten our understanding of the global realities of new democratic possibilities. These include the formation of new "civil cultures of societies." Indeed, the social science literature over the past few decades has begun to study not only new "international" regimes of governance, but also the formation of global civil societies or global public spheres. If Gramsci painted the potential of the formation of such transnational "civil cultures of societies" in the softest of pastels, Benjamin used expressionist colours, as when he intuited, through his "productive-directive" concept of the "aesthetics of public intellectuality," the extraordinary political implications of the concept of "mass intellectuality" in relation to the self-organization of democratic societies. ${ }^{65}$ Of the three of them, Polanyi had the most formidable chro-

65. That Benjamin hoped to counter the rapid subjection of Germany's public spheres to the demagoguery of the Nazi apparatus is apparent from the fact that even as late as 1936 he 
matisity. In many places and in many times, he indicated in his research, societies had demonstrated their capacity for self-organization. ${ }^{66}$ This simply was a fact of world history.

Karl Polanyi noted in his extraordinary study of the evolution of capitalism in Britain that the "great transformations" ushered in by the capitalist revolution of the production processes destroyed traditioned forms of social and cultural life. ${ }^{67}$ As a result, all manner of grass roots movements and forms of organization emerged throughout the $19^{\text {th }}$ century in order to counter the poverty, violence, and marginalization to which the working populations had been subjected by the destructive forces of capitalism. Polanyi developed the concept of "double movement" in order to analyze Britain's $19^{\text {th }}$ century: whereas the capitalist evolution, under the predominant aegis of the doctrine of selfregulating markets, subjected states and societies to the logic of laissez-faire capitalism, through the social capacity of self-organization the populations most effected by this doctrine sought to re-embed their economic activities in communities and social relations. Polanyi's The Great Transformation offers many extraordinary insights into the social and theoretical framing of the evolution of capitalism over the past few centuries. Among his central theses I would like to point to just five: 1) States can accelerate or decelerate the destructive impact of capitalist modes of production on social and cultural life by intervening in the juridical organization of the regulations governing the processes of economic production and trade. 2) The notion of the self-regulated market, as proposed by predominant liberal economic theory, is a historical idea and not a historical fact. It is even less a natural fact based on natural laws. 3) The theories of utilitarianisms, which constitute the basis of liberal economic thought, is based on an ontology which assumes that human beings by nature are invidious, individualist, greedy, and competitive. Anthropological and ethnographic

hoped to participate in the opposition to the Third Reich by rejecting accommodations and conformisms to the violences perpetrated by the supporters of National-Socialism. Publishing under a pseudonym, he offered an edition of beautiful letters written by Deutsche Menschen who were psychologically rooted in the basic ethics of the enlightenment. The simplicity of the prose contrasted with the bombastic ideologies of the regime, as Adorno emphasized in his comments on it. Walter Benjamin [1972] Deutsche Menschen. Eine Folge von Briefen. Suhrkamp Verlag: Frankfurt, Main, Germany. As Adorno explains in an appendixed essay, Benjamin had published these letters in 1931/32 in the important newspaper "Frankfurter Zeitung." While the Nazis attempted to destroy the legacies of the enlightenment, they were ultimately unable to do so, as the predominant philosophical content of the student movement in Germany of the 1960'ies illustrates. Adorno, in spite of his experiences of anti-semitism and exile, reflected similarly on the longevity of enlightenment ideas.

66. Karl Polanyi [1944] The Great Transformation. The political and economic origins of our time. Beacon Press: Boston, MA, USA.

67. The Great Transformation. 
studies do not support such Hobbesian and Maudevillian ontological assumptions as economic activities of production and exchange in many societies are defined by social bonds of "reciprocity" and "redistribution". 4) Markets by nature do not replace basic economic activities such as householding. 5) The marketization of labour, land, and capital under conditions of modern capitalism, in which societies, politics, cultures and nature are subjected to the laissez-faire principle, is not a measure of human progress. It tends towards the destruction of human solidarity, community, and nature alike. ${ }^{68}$

Polanyi clearly corrected Marxism when he rehabilitated the important function of the juridical instruments available to the state for purposes of regulating the protection of the population under conditions of capitalist production and trade. But Polanyi also critiqued the ontological assumptions of predominant economic, social, and political theories in the context of liberalism. His studies in critical anthropology, critical ethnographic work, coupled with his analysis of world economic history in relation to trade and markets of early empires enabled him to discern self regulating social principles in a variety of geographic, economic, and historic contexts. ${ }^{69}$ Thus, for instance, in his work on Dahomey and the Slave Trade, he noted that internal markets subject to regulation functioned independently from external markets. While Whidah, a port of trade on the West African coast engaged with traders from Europe, the king of Dahomey rigorously regulated that trade while simultaneously declaring the internal markets off limits to the foreigners. Although exchange on the internal market was based on money, albeit in the form of cowries, this market did not expand..$^{70}$ Hence there does not obtain an intrinsic propensity for markets to expand, even when a form of money is used in exchange. Dahomey's exchange was thus regulated by internal circuits of money and goods, and not linked to external circulations of capital. Conversely, exchanges on Dahomey's internal market never compromised labour and land. They were not subject to marketization. As a result, social self-organization generated the reproduction of solidarity, reciprocity, trust, and friendship. These social values were not intrinsic to earlier modes of social organization exclusively, Polanyi noted, nor were they exclusively existent at the peripheries of the global economic order. As the counter-movement in the $19^{\text {th }}$ century had indicated, even in the heyday of capitalism in Britain, situated at the very center of transatlantic capitalism,

68. Gregory Baum [1996] pointed out that Polanyi was among the first social thinkers to recognize the damaging impact of the self regulated market upon nature. See his Karl Polanyi. On ethics and economics. McGill Queens University Press: Montreal and Kingston, Canada.

69. Karl Polanyi, Conrad M. Aresnberg and Harry W. Pearson [1957] Trade and Market in the Early Empires. Economies in History and Theory. The Free Press: New York, N.Y., USA.

70. Karl Polanyi [1966] Dahomey and the Slave Trade. University of Washington Press: Seattle, WA, USA and London, UK. 
workers organized themselves for purposes of defending a modicum of collective responsibility in the organization of social and cultural life. If, as Benjamin once wrote in his Theologisch-politisches Fragment, the greatest accomplishment of Bloch resided in the fact that he negated the political significance of theocracy — whereby he simultaneously affirmed the theocratic or religious significance of the belief systems of capitalism - we can state about Polanyi that his greatest achievement resides in his negation of the negation of the selfregulating capacities of societies promoted by all manner of neo-liberal social sciences. Indeed, it was fascism's central intent to eliminate such self-regulating social and cultural capacities from its corporativist state, as it designed social policies for purposes of forcing self-regulating social capacities into compromise, conformism, accommodation and complicity with the fascist state. ${ }^{71}$ It thus eliminated the substance of democracy.

Polanyi's analysis of the self-regulating capacities of societies in relation to land, capital, and labor constitutes his central "productive-directive" concept. The fact that the values of solidarity, trust, friendship, and reciprocity he discovered in self-regulating societies were surely also central to many of the social movements and students movements of the 1960's is particularly impressive if we take into account that young generations in the most affluent global regions had the capacity to insist on collectively imagine such values, all demagoguery and propaganda about the absolute values of unlimited accumulation and consumption to the contrary. The desire for transparency in the constructions of social relations has also been at work in recent attempts over the past decades or so on the part of many indigenous movements around the world, from the Zapatistas in Mexico to the struggles of "first peoples" in New Zealand, Bolivia, and Peru. ${ }^{72}$ At issue is the self-organization own social and economic relations, particularly as it pertain to labor, land, water, and other natural resources. The self-organizing capacities Polanyi traced historically and geographically have now been inhanced through the invention, use, and application of information technologies, which includes the world wide web and the internet. This has facilitated the organization of new circuits of exchange of information on a global scale in relation to the formation of "civil cultures of societies. Benjamin's "public intellectuality" and Polanyi"s "societies of reciprocities", linked with Gramsci's concept of the building of "civil cultures of societies" are of great significance in this

71. Karl Polanyi, “The Essence of Fascism,” John Lewis, Karl Polanyi, and Donald K. Kitchin, eds. [1935] Christianity and the Social Revolution. Books for Libraries Press: Freeport, N.Y., USA. pp. 359-394.

72. Jeffrey Sissons [2005] First Peoples. Indigeneous Cultures and Their Futures. Reaktion Books: London, UK. And: Richard Howson and Kylie Smith [2008] Hegemony. Studies in Consensus and Cocercion. Routledge: London, UK. 
context, because our contemporary "social time" as well as "social space" are now inseparably intertwined with the "information age." This affiliation endows social space and time with new historic possibilities towards accelerating and expanding the processes of liberation and emancipation from structures of thought steeped in violence. Such structures include theories of violence including just war theories.

No doubt, Benjamin, Gramsci and Polanyi developed their democratic theories under the impact of their personal experiences of historically unprecedented collective rights oriented movements and events. The workers council movement in Turin for one, in the case of Gramsci, the municipal movement in Vienna, for another, in the case of Polanyi, and, in the case of Benjamin, the extraordinary general strikes and demonstrations which brought millions of citizens into the streets of the German and European cities. But they also developed their liberation theories under great duress, when fascist and Nazi demagogues managed to divide mass societies into through images of exceptionalist nationalisms. Central to such images is the concept of the "superiority of the individual." The power of the "productive-directive" concepts of Benjamin, Gramsci, and Polanyi alike resides in the fact that they stated with great clarity against the background of fascism and Nazism that it is not individuals, but people together, who produce a surplus in sustenance and thus the trade in it, and that people, together, in community, are capable of self-regulating production, trade, and exchange. And just as individuals do not constitute the basis of communities, individual nation states equally do not constitute the basis of global communities. As new circuits of communicative potentials now link the self-regulating collective efforts on global trajectories of rights expansions, Benjamin's concept of "mass-intellectuality," Gramsci's concept of "civil cultures of societies," and Polanyi's concept of "societies of reciprocities" continue to "tremble with reflections of the future." It is now our responsibility to detect new conceptual and practical possibilities for liberation under the conditions of our "social space" and our "social times" as we move along the first quarter of the $21^{\text {st }}$ Century.

\section{Selected Bibliography}

Adorno, Theodor W. Adorno [1970] Ueber Walter Benjamin. Suhrkamp: Frankfurt, Germany.

Arendt, Hannah [1971] Walter Benjamin, Bertold Brecht. Zwei Essays. R. Piper: Munich, Germany.

Baum, Gregory [1996] Karl Polanyi. On ethics and economics. McGill Queens University Press: Montreal and Kingston, Canada.

Benjamin, Walter [1972] Deutsche Menschen. Eine Folge von Briefen. Suhrkamp Verlag: Frankfurt, Main, Germany. 
- [1971] Zur Kritik der Gewalt und andere Aufsaetze. Mit einem Nachwort von Herbert Marcuse. Suhrkamp Verlag: Frankfurt/Main, Germany

— [1974] Der Stratege im Literaturkampf. Suhrkamp Verlag: Frankfurt/Main, Germany.

- [1980] Illuminationen. Suhrkamp Verlag, Frankfurt/Main, Germany.

— [1980] ,Das Kunstwerk im Zeitalter seiner technischen Reproduzierbarkeit." In Illuminationen. Suhrkamp Verlag: Frankfurt/Main. Germany. pp. 136-70.

- [1996] Selected Writings, Volume 1, 1913-1926, Eds Marcus Bullock and Michael W. Jennings. Harvard University Press: Cambridge, MA, USA and London, UK.

- [1971] Zur Kritik der Gewalt und andere Aufsaetze. Mit einem Nachwort von Herbert Marcuse. Suhrkamp Verlag, Frankfurt/Main, Germany. pp. 29-66.

— [1974] Der Stratege im Literaturkampf. Suhrkamp Verlag: Frankfurt/Main, Germany.

Berghahn, Klaus L. [2006] "Schillers Aesthetische Utopie." In Regionaler Kulturraum und intellektuelle Kommunikation vom Humanismus bis ins Zeitalter des Internet. Festschrift fuer Klaus Garber. Ed Axel E. Walter. Rodopi: Amsterdam, Netherlands and New York, USA. Bernays, Edward L. [1923] Crystallizing Public Opinion. New York, NY, USA.

Bernays, Edward L [2005] Propaganda. Intro Mark Crispin Miller. Ig Publishing: Brooklyn, New York, N.Y., USA. Original edn 1928.

Bieler, Andreas and Adam David Morton [2006] Images of Gramsci. Connections and contentions in political theory and international relations. Routledge: London, UK.

BLoch, Ernst [1959] Das antizipierende Bewusstsein. Suhrkamp Verlag: Frankfurt, Germany.

- [1972] Naturrecht und menschliche Würde. Suhrkamp: Frankfurt, Germany.

Bоввіо, Norberto [1969] "Gramsci e la concezione della societa civile." In Gramsci e la Cultura Contemporanea. Ed Pietro Rossi. Editori Riuniti-Istituto Gramsci: Rome, Italy. pp. 75-101.

Borg, Carmel and Peter Mayo [2007] Public Intellectuals, Radical Democracy and Social Movements. Peter Lang: New York, N.Y., USA.

Brodersen, Momme [2005] Walter Benjamin. Suhrkamp Verlag: Frankfurt/Main, Germany.

Buroway, Michael [2003] "For a Sociological Marxism: The Complementary Convergence of Antonio Gramsci and Karl Polanyi." Politics and Society, vol. 31, No. 2. pp. 193-261.

CASTELLS, Manuel [2009] (http://annenberg.usc.edu/Faculty/Communication/CastellsM. aspx)

Cesaire, Aime [1972] Discourse on Colonialism. Tr Joan Pinkham. Monthly Review Press: New York, N.Y., 1972. Original French edn 1955

Chakrabarty, Dipesh [2000] Provincializing Europe. Postcolonial Thought and Historical Difference. Princeton University Press: Princeton, N.J., USA.

Chatterjee, Partha [2006] The Politics of the Governed: Reflections on Popular Politicis in Most of the World.

Du BoIs, W.E. Burghardt [1996] The World and Africa. An inquiry into the part which Africa has played in world history. International Publishers: New York, N.Y., USA. First edn 1946. 
Fanon, Frantz [1964] Toward the African Revolution. Tr Haakon Chevalier. Grove Press: New York, N.Y., USA.

FeyerABEND, Paul [1987] Farewell to Reason. Verso: London, UK and New York, USA. Geschichte der deutschen Literatur. Vom Ausgang des 19. Jahrhunderts bi 1917. [1974] Volk und Wissen Volkseigener Verlag: Berlin, Germany.

Gobetti, Piero [1995] La filosofia politica di Vittorio Alfieri. Grafiche Cesari: Ascoli Piceno, Italy. Written in 1922.

Gowan, Peter and Perry Anderson. Eds. [1997] The Question of Europe. Verso: London, UK.

Gramsci, Antonio [1977] Quaderni del Carcere. Ed Valentino Gerratana. 4 Vol. Einaudi: Turin, Italy.

— [1995] The Southern Question. [1995] Tr and intro Pasquale Verdicchio. Bordighera Incorporated: West Lafayette, IN, USA. Original edn 1926.

Heller, Agnes [1978] Renaissance Man. Schocken Books: New York, N.Y., USA. Original Hungarian edn 1967.

Hetmann, Frederic [2004] Reisender mit schwerem Gepaeck. Beltz Verlag: Weinheim, Germany.

Holub, Renate [1992] Antonio Gramsci. Beyond Marxism and Postmodernism. Routledge: London, UK.

- [1997]. "Hannah Arendt Not Among the Germans: Intellectuals, "Intellectual Fields" and "Fields of Knowledge." p. 31. (http://learning.berkeley.edu/holub/ar ticles/Hanagf.pdf).

- [2001] "The future of the Social Sciences." In Journal of Social Sciences, Chulalongkorn University, Bangkok, Thailand, Vol 32, No 1. Ed. Chaiyan Chaiyaporn. pp. 1-36.

- [2003] "Transcommunality in a Global World." In John Brown Childs. Transcommunality. From the Politics of Conversion to the Ethics of Respect. Temple University Press: Philadelphia, USA. pp. 146-157.

Howson, Richard and Kylie Smith, Eds. [2008] Hegemony. Studies in Consensus and Coercion. Routledge: London, UK.

Kanoussi, Dora [2000] Ed Gramsci en America. Universita Autonoma di PueblaPlaza y Valdes Editores- International Gramsci Society: Puebla, Mexico.

- [2004] Ed Poder y hegemonía hoy. Gramsci en la era global. Universita Autonoma di Puebla-Plaza y Valdes Editores- International Gramsci Society-Fondazione Istituto Gramsci: Puebla, Mexico and Rome, Italy.

KEBIR, Sabine [1999] "L'internazionalismo di Gramsci e i problemi odierni della sinistra." In Giorgio Baratta and Guido Liguori. Eds Gramsci da un secolo all'altro. International Gramsci Society and Editori Riuniti: Rome, Italy. pp. 211-217.

KoHan, Martin. [2004] Zona urbana: ensayo de lectura sobre Walter Benjamin. Grupo Editorial Norma, Buenos Aires, Argentina.

KolakowsKi, Leszek [1978] Main Currents of Marxism. Its Origins, Growth, and Dissolutions. Tr P.S. Falla. Oxford University Press: Oxford, UK.

KONDER, Leandro. [1988] Walter Benjamin: o marxismo da melancolia. Campus, Rio de Janeiro, Brazil.

Kunn, Thomas [1962] The Structures of Scientific Revolutions. The University of Chicago Press: Chicago, Ill., USA. 
Levesque, Benoit [1989] Ed L'autre economie. Presses de l'Université du Quebec: Montréal, Canada.

LipPmann, Walter [1955] The Public Philosophy. Mentor Books: New York, NY, USA. Lowy, Michael. [2001] Walter Benjamin; avertissement d'incendie: une lecture des theses sur le concept d'histoire. Presses Universitaires de France, Paris, France.

MarZani, Carl [1957] Ed and Tr The Open Marxism of Antonio Gramsci. Cameron Associates: New York, NY, USA.

Mendell, Marguerite and Daniel Salee [1991] Eds The Legacy of Karl Polanyi. St Martin's Press: New York, N.Y., USA.

Polanyi, Karl "The Essence of Fascism." In John Lewis, Karl Polanyi, and Donald K. Kitchin, eds. [1935] Christianity and the Social Revolution. Books for Libraries Press: Freeport, N.Y., USA. pp. 359-394.

- [1944] The Great Transformation. The political and economic origins of our time. Beacon Press: Boston, MA, USA.

Polanyi, Karl, Conrad M. Aresnberg and Harry W. Pearson [1957] Trade and Market in the Early Empires. Economies in History and Theory. The Free Press: New York, N.Y., USA.

Polanyi-Levitt, Kari [1990] Ed The Life and Work of Karl Polanyi. Black Rose Books: Montreal, Canada.

PonzI, Mauro [1993] Walter Benjamin e il moderno. Bulzoni: Rome, Italy.

Portantiero, Juan Carlos [1999] Los usos de Gramsci. Grijalbo conceptos: Buenos Aires, Argentina.

Proto, Mario [1999] Ed Gramsci e l'Internazionalismo. Nazione, Europa, America Latina. Piero Lacaita Editore: Manduria, Bari, Rome, Italy.

Ricardo, Michel Mjica [1994] Democracia sustantiva, Democracia Formal y Hegemonia en Antonio Gramsci. Academia Nacional de la Historia: Caracas, Venezuela.

Ringer, Fritz K [1969] The Decline of the German Mandarins. The German Academic Community, 1890-1933. Harvard University Press: Cambridge, MA, USA.

RINGER, Fritz [1997] Max Weber's Methodology. The Unification of the Cultural and Social Sciences. Harvard UP: Cambridge, MA, USA and London, UK.

Russi, Luciano [1981] Nascita di una nazione. Ideologie politiche per l'Italia [18151861]. Clua: Pescara, Italy.

SARLo, Beatriz [2000] Siete ensayos sobre Walter Benjamin. Fondo de Cultura Economica de Argentina: Buenos Aires, Argentina.

SARTRE, Jean Paul [1972] plaidoyer pour les intellectuels [1972] Gallimard: Paris, France.

SCHUMPeTER, Joseph A. [1954] History of Economic Analysis. With a New Introduction by Mark Perelman. Oxford University Press: New York, USA.

Scholem, Gershom and Theodor W. Adorno [1994] Eds The Correspondence of Walter Benjamin. 1910-1940. Trs Manfred R. Jacobson and Evelyn M. Jacobson. The University of Chicago Press: Chicago, ILL. USA.

Sissons, Jeffrey [2005] First Peoples. Indigeneous Cultures and Their Futures. Reaktion Books: London, UK.

TARrow, Sidney [2006] The New Transnational Activism. Cambridge University Press: Cambridge, UK. 
Therborn, Goran [1997] Europe in the Twenty-first Century. In Peter Gowan and Perry Anderson. Eds. The Question of Europe. Verso: London, UK. Pp. 357-85.

Tilly, Charles [2004] Contention and Democracy in Europe, 1650-2000. Cambridge University Press: Cambridge, UK. Sidney Tarrow [2006] The New Transnational Activism. Cambridge University Press: Cambridge, UK.

VACCA, Guiseppe and Giancarlo Schirru, Eds [2007] Studi gramsciani nel mondo 2000-2005. Il Mulino: Bologna, Italy.

Weber, Max [2003] The Protestant Ethic and the Spirit of Capitalism. Tr Talcott Parsons. Foreword by R.H. Tawney. Dover Publications, INC. Mineola: New York, USA. Original German edn 1905 and 1920.

WolfF, Kurt H. [1993] Ed From Karl Mannheim. 2nd expanded edn. With an Introduction by Volker Meja and David Kettler. Transaction Publishers: New Brunswick (U.S.A.) and London (U.K.). Original edn 1971. 